\title{
Nutritional, antioxidant and organoleptic properties of therapeutic-complementary-food formulated from locally available food materials for severe acute malnutrition management
}

\author{
Oluwole Steve ljarotimi, Monisola Rachael Fatiregun and Timilehin David Oluwajuyitan ${ }^{*}$ (1)
}

\begin{abstract}
Background: The prevalence of severe acute malnutrition among children ( $<5$ years) due to low energy-protein density of local complementary foods and poor feeding practices is a great concern in developing countries, Nigeria inclusive. Hence, the aimed of this study was to formulate and evaluate the chemical composition, functional, antioxidant and organoleptic properties of low-cost complementary foods from locally accessible food material using household technologies. Using UNCEF guidelines, three complementary foods were formulated and their nutritional characteristics were compared with local complementary food (100\% sorghum) and ready-to-using therapeutic food.

Results: Protein $(\mathrm{g} / 100 \mathrm{~g}$ ) and energy values (kcal./100 g) of formulated complementary foods varied from 16.16 to 16.93 and 418.08 to 474.13 , respectively, and were significantly $(p<0.05)$ higher than OG $(7.72 ; 378.71)$ (a 100\% sorghum flour), but lower than P0 (539.8) (a read-to-eat therapeutic food). Mineral elements ( $\mathrm{mg} / 100 \mathrm{~g})$ in the food samples were K (4175-6350.5), Ca (341.5-949), Fe (23.5-50.5) Zn (28-38.5), P (3855.6-4501), and Na (343.5-950.5), and were significantly lower than in PO, but higher in K, Fe and Zn than for OG. Sodium/Potassium and Calcium/Phosphorous molar ratios of the complementary foods ranged from 0.16 to 0.92 and 0.07 to 0.16 and were lower than P0 ( 0.64 , $0.19)$ and $O G(1.71,0.2)$, respectively. Total essential amino acids ( $\mathrm{g} / 100 \mathrm{~g}$ protein) of the food samples varied from 23.53 to 25.94 , and were comparable to OG (28.40) and PO (32.74). Predicted biological value and essential amino acid index of P2 sample $(53.53 \%, 59.85 \%)$ had the highest values, while P1 $(46.0 \%, 52.94 \%)$ had the lowest, and these values were comparatively lower than PO (67.53\%, 72.69\%), OG (55.91\%, 62.03\%), and recommended value (> 70\%). Functional properties varied from 0.61 to $0.83,124.2$ to $176.2,102.2$ to $257.19,0$ to 1 and 164.7 to 373.3 for bulk density, oil absorption capacity, water absorption capacity, least gelation and swelling capacity, respectively. Antioxidant activity of formulated complementary foods ranged from 2.07 to $3.24 \%, 8.61$ to $9.87 \mathrm{mg} / \mathrm{g}, 21.6$ to $40.95 \%$ and 62.42 to $87.0 \%$ for DPPH, FRAP, Fe-chelation and OH-free radicals, respectively, and were significantly $(p<0.05)$ higher than in OG and PO. Sample P1 was significantly $(p<0.05)$ rated highest in appearance, aroma, taste, texture and overall acceptability above $\mathrm{P} 2$ and $\mathrm{P3}$.
\end{abstract}

Conclusion: The formulated complementary foods had enough nutrient and energy values to meet the requirements for infants as recommended for complementary foods and for amelioration of severe acute malnutrition in children. Nutritional and sensory evaluation revealed that addition of full fat milk to the P1 sample significantly improved its nutrient composition and organoleptic quality and contributed to its high acceptance compared to

*Correspondence: tdoluwajuyitan@futa.edu.ng

Department of Food Science and Technology, Federal University

of Technology, Akure, Nigeria

(c) The Author(s) 2022. Open Access This article is licensed under a Creative Commons Attribution 4.0 International License, which permits use, sharing, adaptation, distribution and reproduction in any medium or format, as long as you give appropriate credit to the original author(s) and the source, provide a link to the Creative Commons licence, and indicate if changes were made. The images or other third party material in this article are included in the article's Creative Commons licence, unless indicated otherwise in a credit line to the material. If material is not included in the article's Creative Commons licence and your intended use is not permitted by statutory regulation or exceeds the permitted use, you will need to obtain permission directly from the copyright holder. To view a copy of this licence, visit http://creativecommons.org/licenses/by/4.0/. 
other formulations. Therefore, this complementary food is potentially suitable for use as complementary food and diet to manage severe acute malnutrition in Nigeria and other developing countries. However, there is a need for biological evaluation.

Keywords: Affordable local food materials, Homemade complementary foods, Acceptability, Protein-energy malnutrition

\section{Background}

Traditional complementary foods usually produced from cereals in the developing countries are characterized with low protein, energy density and micronutrient (Shiriki et al. 2015; Adepoju and Ayenitaju 2021). Hence, poor quality and inadequate complementary foods have been implicated as the main causes of growth and cognitive development retardation, increase in the risk of morbidity and mortality in children (Black et al. 2008; Rogol et al. 2021; Yamashiro 2021). Evidences have established that complementary feeding period is the time when malnutrition starts in many infants contributing significantly to the high prevalence of malnutrition in children worldwide (Daelmans and Saadeh 2003; Maciel et al. 2021). Adequate nutrition, i.e., qualitative complementary food, has been listed as one of the preventive measures that would reduce growth faltering, morbidity and mortality in children under the age of five years (Campos et al. 2010; Barcus et al. 2021). Adoption of appropriate quality and quantity of complementary foods are essential components of optimal nutrition for infants and young children (Lutter and Rivera 2003; Holdoway 2021).

Complementary foods are foods (solids or liquids) required after 6 months when breastmilk alone is no longer sufficient to provide necessary nutrient requirements for the growing infant (Mildon et al. 2021). At about six months of age, the supply of energy and some nutrients from breast milk is no longer adequate to meet an infant's needs (Koletzko et al. 2008; Ijarotimi and Keshinro 2013; Mildon et al. 2021). Consequently, complementary foods, preferably with a relatively high energy and nutrient density, must be provided. In many developing countries, cereals or starchy roots and tubers are used for the production of complementary foods (Gibson et al. 1998a, b; Irenso et al. 2021). They are usually prepared as thin gruels, and characterized with low essential nutrients (protein and micronutrients) and energy density (Gibson et al. 1998a, b; Shiriki et al. 2015). These inadequacies further exacerbated nutritional integrity of infants, particularly when receive in low quantity per day couple with the limited numbers of frequency with which they are fed and responsiveness of the mother or caregiver to the needs of the child during feeding (Pelto et al. 2003; Martin et al. 2021). In recent decades, scientific report has emphasized the use of local complementary foods formulated in the home rather than centrally produced fortified foods particularly for those mothers with limited access to commercial complementary foods (Masanja et al. 2021; Mekuria et al. 2021; Rai 2021).

Sorghum (Sorghum bicolor) is a good source of proteins, calories and minerals for millions of people in developing countries (Adejuwon et al. 2021). Duodu et al. (2003) reported that sorghum is inexpensive and nutritionally comparable or even superior to other major cereals. Sorghum is ranked third in the world among cereals for human consumption, after rice and wheat (Elemo et al. 2011; Mohammed et al. 2011; Gajmal et al. 2021). In Nigeria, sorghum is used for the production of fermented local complementary food or breakfast meal known as Ogi. However, sorghum is low in essential nutrients like protein and minerals (Tripathi et al. 2021).

Soybean (Glycine max) belongs to the family leguminosae and sub-family papillionnideae. Soybean is a very cheap source of plant protein for both animals and man, and is leading source of edible oils and fats (Alabi and Oluwatosin 2001; Oluwajuyitan et al. 2021). Soybean seeds contain high quantity of protein and its amino acid composition is approximate to composition of animal proteins, therefore is often used as replacement component of meat protein (Banaszkiewicz 2011). The biological utilization of soy protein is lower than that of animal protein due to limitations in some essential amino acids and the presence of phytochemicals with antinutritional effects such as protease inhibitors (Wang et al. 2014; Carral et al. 2021). These compounds inhibit the proteolytic enzymes and, consequently, reduce protein digestion leading to a decrease in weight gain and growth of animals (Miura et al. 2005). However, these compounds are thermolabile and can be inactivated by heat treatment (Dong et al. 2021).

Groundnut (Arachis hypogaea L.) also known as peanut or earthnut is an important legume, and widely cultivated in Nigeria. Groundnut is a native to a region in eastern South America (Malati 2021), and is now grown worldwide in the tropical and temperate zones primarily as an oil seed crop (Awopetu 2021). Nutritionally, groundnut kernel contain oil (44-56\%), protein (22-30\%), and appreciable amount of essential amino acids, fatty acids and micronutrients (Asibuo et al. 2008; Atasie et al. 2009; $\mathrm{Yu}$ et al. 2021). In many parts of developing countries, 
groundnut kernel is used in food preparation in order to improve the protein, taste and flavour (Asibuo et al. 2008; Gbadebo and Ahmed 2021). The vast food preparations incorporating groundnut to improve the protein level has helped in no small way in reducing malnutrition in the developing countries (Asibuo et al. 2008; Dean 2021).

Orange-fleshed sweet potato (OFSP) is a root crop largely grown in tropical countries. It is rich in $ß$-carotene, polyphenols, ascorbic acid, carbohydrates, dietary fibre and essential minerals (Van Hal 2000; Azeem et al. 2020). Previous study showed various application of OFSP flour in the development of food products like bread and infant formula (Chikpah, et al. 2020; Adejuwon et al. 2021).

Moringa oleifera is an indigenous edible plant found abundantly in the dry tropics, and grows all the year round (González-Burgos et al. 2021). The leaves, pods and flowers of this plant, which are used as vegetable in many parts of the world have great nutritional value (Shiriki et al. 2015; González-Burgos et al. 2021). The leaves contain highly digestible proteins and also rich in micronutrients like iron, calcium, vitamin $\mathrm{C}$, and carotenoids (Shiriki et al. 2015; Mounika et al. 2021). The leaves have therapeutic value (Mounika et al. 2021; Bailey-Shaw et al. 2021), because, it is used for the treatment of protein and micronutrient deficiencies among children in some countries in Africa (Muflihatin et al. 2021). Moringa oleifera leaf powder has been added to a local maize-based complementary food in Nigeria, resulting in significant improvement in protein, iron status, serum ferritin, and serum retinol of infants aged 6-12 months (Nnam 2009; Shiriki et al. 2015; Boateng et al. 2018).

The local sorghum-based infant food is low in essential nutrients like protein and micronutrients, which has been implicated as the main cause of high prevalence of protein-energy malnutrition among the weaning-aged children (6-24 months) in Africa. In view of this, there is a need to formulate therapeutical-complementary food using locally available food materials like sorghum, soybean, orange-fleshed sweet potato, groundnut, and moringa leaf as an alternate to non-availability of ready-to eat therapeutical food produced by the UNICEF for the management of severe acute malnutrition (SAM).

\section{Methods}

\section{Sources of materials}

Orange fleshed sweet potato (Ipomea batatas L.) were obtained from Agricultural Institute, Eruwa, Oyo state, Nigeria. Moringa leaves (Moringa oleifera) and soybean cake (Glycine max) were obtained from a local farm and Rom mill factory, Ibadan, Oyo state, Nigeria, respectively. Sorghum (Sorghum bicolor), groundnut kernels and other ingredients (mineral mix, full fat milk, sugar and Soy bean oil) were purchased from Erekesan Market, Akure, Ondo State, Nigeria.

\section{Sample preparation \\ Production of sorghum flour}

The sorghum flour was prepared as described by Ijarotimi et al. (2011) with slight modification. Sorghum grains were sorted to remove foreign materials, washed with distilled water and soaked in distilled water at room temperature for three days. Thereafter, the grains were thoroughly washed, drained, wet milled, sieved with muslin cloth, decanted, and the slurry was oven dried with a hotair oven (Plus11 Sanyo Gallenkamp PLC, Loughborough, Leicestershire, UK) at $60{ }^{\circ} \mathrm{C}$ for $20 \mathrm{~h}$., The oven dried sorghum flour was re-milled (Laboratory blender (Model KM 901D; Kenwood Electronic, Hertfordshire, UK) and sieved with a $200 \mathrm{~mm}$ wire mesh sieve (British Standard). The flour was packed in a plastic container, sealed and stored at room temperature $\left(\sim 27^{\circ} \mathrm{C}\right)$ until used.

\section{Production of groundnut flour}

The groundnut kernels $(1 \mathrm{~kg})$ were manually sorted to remove foreign substances; and the kernels were thoroughly washed with distilled water, drained, oven dried in hot-air oven (plus11 Sanyo Gallen Kamp plc) at $60{ }^{\circ} \mathrm{C}$ for $20 \mathrm{~h}$. After oven dried, the kernels were milled using Philip laboratory blender (model HR2811), and sieved using a $60 \mathrm{~mm}$ mesh sieve (British standard) to obtain raw groundnut kernel flour sample (RGN). The flour samples were separately packed in a plastic zip lock bag and stored at room temperature $\left(\sim 27^{\circ} \mathrm{C}\right)$ until used.

\section{Production of moringa leaf powder}

Moringa oleifera leaf powder was prepared using a modification of the method described by Gernah and Sengev (2011). The freshly harvested moringa leaves (500 g) were washed with distilled water, oven dried in a hot-air oven (Plus11 Sanyo Gallenkamp PLC, Loughborough, Leicestershire, UK) at $40{ }^{\circ} \mathrm{C}$ for $6 \mathrm{~h}$, and milled in a laboratory blender (Model KM 901D; Kenwood Electronic, Hertfordshire, UK), and sieved using a $60 \mathrm{~mm}$ mesh sieve (British standard). The moringa powder was packed in a plastic zip lock bag and stored at room temperature $\left(\sim 27^{\circ} \mathrm{C}\right)$ until used.

\section{Production of orange fleshed sweet potato (OFSP) flour}

Orange fleshed sweet potato (OFSP) flour was produced according to the method of Adejuwon et al. (2021), with slight modification. OFSP tubers were washed, peeled manually with knives, sliced into uniform sizes of $3 \mathrm{~mm}$ thickness using an electrical slicing machine (Ritter E16, Ritter GmbH, Germany). The slices were soaked in $5 \mathrm{~g} / \mathrm{L}$ sodium metabisulphite solution for $5 \mathrm{~min}$ to prevent 
browning, pretreated slices were oven dried in a hot-air oven (Plus11 Sanyo Gallenkamp PLC, Loughborough, Leicestershire, UK) at $60{ }^{\circ} \mathrm{C}$ for $12 \mathrm{~h}$, milled in a laboratory blender (Model KM 901D; Kenwood Electronic, Hertfordshire, UK), and sieved using a $60 \mathrm{~mm}$ mesh sieve (British standard). The OFSP flour was packed in a plastic zip lock bag and stored at room temperature $\left(\sim 27^{\circ} \mathrm{C}\right)$ until used.

\section{Production of defatted soybean (soycake) flour}

The soy-cake flour was cleaned, oven dried at $60{ }^{\circ} \mathrm{C}$ for $4 \mathrm{~h}$ in a hot-air oven (Plus11 Sanyo Gallenkamp PLC, Loughborough, Leicestershire, UK), milled (Laboratory Blender (Model KM 901D; Kenwood Electronic, Hertfordshire, UK) and sieved through a $200 \mathrm{~mm}$ mesh sieve (British Standard). The defatted soybean flour was packed was in a plastic zip lock bag and stored at room temperature $\left(\sim 27^{\circ} \mathrm{C}\right)$ until used.

\section{Formulation of therapeutic foods}

The food samples were formulated using the guidelines of UNICEF (2016), and the following food combinations were produced: P0 (a control sample, full fat milk 30\%, peanut $25 \%$, soybean oil $15 \%$, sugar $28 \%$, mineral mix $2 \%$ ), P1(Orange-fleshed sweet potato $26.5 \%$, sorghum $26.5 \%$, full fat milk $30 \%$, soybean oil $5 \%$, sugar $10 \%$, moringa leaves 2\%) P2 (Soycake 15\%, Orange fleshed sweet potato $26.5 \%$, sorghum $26.5 \%$, full fat milk $15 \%$, soybean oil $5 \%$, sugar $10 \%$, moringa leaves $2 \%$ ) P3 (Soycake 30\%, Orange fleshed sweet potato $26.5 \%$, sorghum $26.5 \%$, soybean oil $5 \%$, sugar $10 \%$, moringa leaves $2 \%$ ) and OG (a local complementary food, $100 \%$ sorghum). The resultant mixture was mixed using a Umthric mixer for 15 min per formulation. The slurry form of $\mathrm{P} 0$ and blended flour of P1, P2 and P3 were tightly packed in plastic containers, respectively and stored at room temperature $\left(\sim 27{ }^{\circ} \mathrm{C}\right)$ until used (Table 1).

\section{Ethical approval}

The study protocol was approved by the Ethical Committee School of Agriculture and Agricultural Technology, Federal University of Technology, Akure, Nigeria (FUTA/ SAAT/2020/019).

\section{Chemical analysis of therapeutic food}

Determination of proximate composition of therapeutic food The moisture, ash, crude fiber, crude fat and crude protein contents of sorghum-based breakfast meal samples were determined using AOAC (2012) methods. The carbohydrate content was determined by difference as follows:

$$
\begin{aligned}
\text { Carbohydrate }(\%)= & 100-(\% \text { Moisture }+\% \text { Fat }+\% \text { Ash } \\
& +\% \text { Crude fibre }+\% \text { Crude protein }) .
\end{aligned}
$$

The gross energy values (Kcal/100 g) of the samples were calculated by using formula described by Iombor et al. (2009).

\section{Determination of mineral composition of therapeutic food}

The mineral composition (i.e. $\mathrm{Ca}, \mathrm{Mg}, \mathrm{Fe}, \mathrm{Cu}$ a +566 nd $\mathrm{Zn}$ ) of the sorghum-based meals was determined using Atomic Absorption Spectrophotomete $+r$ (AAS Model SP9). The $\mathrm{Na}$ and $\mathrm{K}$ content was determined using flame emission photometer (Sherwood Flame Photometer 410, Sherwood Scientific Ltd. Cambridge, UK) with $\mathrm{NaCl}$ and $\mathrm{KCl}$ as the standards (AOAC 2012). The phosphorus was determined using the Vanodo-molybdate method (Jastrzębska 2009). The $\mathrm{Na} / \mathrm{K}$ and $\mathrm{Ca} / \mathrm{P}$ molar ratios and phytate/mineral molar ratios, that is, Phytate/Zn, $\mathrm{Ca} /$ Phytate and $[\mathrm{Ca}][$ Phytate $] /[\mathrm{Zn}]$ were calculated as described by Ferguson et al. (1988).

\section{Determination of amino acid profile of therapeutic food}

Amino acid content was determined using Pico-Tag method as previously described by Bidlingmeyer et al.

\begin{tabular}{|c|c|c|c|c|c|}
\hline Ingredients & $\begin{array}{l}\text { Local food } \\
\text { (OG) }\end{array}$ & $\begin{array}{l}\text { Product } 0 \\
\text { (P0) }\end{array}$ & $\begin{array}{l}\text { Product } 1 \\
\text { (P1) }\end{array}$ & $\begin{array}{l}\text { Product } 2 \\
\text { (P2) }\end{array}$ & $\begin{array}{l}\text { Product } 3 \\
\text { (P3) }\end{array}$ \\
\hline Full fat milk & - & 30 & 30 & 15 & - \\
\hline Soycake & - & - & - & 15 & 30 \\
\hline Peanut & - & 25 & - & - & - \\
\hline Soy oil & - & 15 & 5 & 5 & 5 \\
\hline Sugar & - & 28 & 10 & 10 & 10 \\
\hline Mineral mix & - & 2 & - & - & - \\
\hline Moringa leaves flour & - & - & 2 & 2 & 2 \\
\hline OFP & - & - & 26.5 & 26.5 & 26.5 \\
\hline Sorghum & 100 & - & 26.5 & 26.5 & 26.5 \\
\hline Total & 100 & 100 & 100 & 100 & 100 \\
\hline
\end{tabular}

Table 1 Formulation of therapeutic complementary foods 
(1984). The cysteine and methionine (sulphur-containing amino acids) were determined after perfomic acid oxidation as described by Gehrke et al. (1985) and tryptophan was determined after alkaline hydrolysis as described by Landry et al. (1992). Briefly, sample was hydrolysed, evaporated in a rotary evaporator and loaded into Technicon Sequential Multi-Sample Amino Acid Analyser (TSM-1) (Technicon Instruments Corporation, New York, USA). $10 \mu \mathrm{L}$ of each hydrolysate was dispensed into the cartridge of the analyser. The analyser was separated and analysed free acidic, neutral and basic amines, which was last for $76 \mathrm{~h}$. Norleucine was employed as the internal standard. Ten microliter $(10 \mu \mathrm{L})$ of the standard solution mixture of the amino acid was also loaded into the analyser. Values of both the standard and samples was recorded and printed out as chromatogram peaks by the chart recorder.

Calculation from the peaks The net height of each peak produced on the chromatogram (each representing amino acid) was measured. The half-height of each peak was located and the width of the peak at half-height will accurately be measured. Approximate area of each peak was then obtained by multiplying the height with the width of the half height.

\section{Determination of fatty acids profile of therapeutic food}

The composite flour samples were extracted with chloroform:methanol $(2: 1 \mathrm{v} / \mathrm{v})$ and solid non-liquid material was removed by filtration. The total extracted lipid material was recovered after solvent removal in a stream of nitrogen. The samples were re-dissolved in anhydrous chloroform/methanol (19:1 v/v), and clarified by centrifugation at $10,000 \times g$ for $10 \mathrm{~min}$. Tranmethylation was performed using $14 \%(\mathrm{w} / \mathrm{v})$ boron triflouride $\left(\mathrm{BF}_{3}\right)$ in methanol (Solomon and Owolawashe 2007). Fifty nanograms of heptadecanoic acid (internal standard) and $1 \mathrm{~mL}$ aliquot of each sample were transferred to a $15 \mathrm{~mL}$ Teflon-lined screw-cap tube. After removal of solvent by nitrogen gassing, the samples were mixed with $0.5 \mathrm{ml}$ of $\mathrm{BF}_{3}$ reagent $(14 \% \mathrm{w} / \mathrm{v})$, placed in warm bath at $100{ }^{\circ} \mathrm{C}$ for $30 \mathrm{~min}$ and cooled. After the addition of saline solution, the transmethylated fatty acids were extracted into hexane. A calibration mixture of fatty acid standards was processed in parallel. Aliquots of the hexane phase were analyzed by gas chromatography. Fatty acids were separated and quantified using a Hewlett-Packard gas chromatograph (5890 Series II) equipped with a flameionization detector. Two microliter aliquot of the hexane phase were injected in split-mode onto a fused silica capillary column (Omegawax: $30 \mathrm{~m} \times 0.32 \mathrm{~mm}$ ID, Supleco, Bellefonte, PA). The injector temperature was set at $200{ }^{\circ} \mathrm{C}$, detector at $230{ }^{\circ} \mathrm{C}$, oven at $120{ }^{\circ} \mathrm{C}$ initially, then $120-205^{\circ} \mathrm{C}$ for $18 \mathrm{~min}$.The carrier gas was helium and the flow rate was approximately $50 \mathrm{~cm} / \mathrm{s}$. Electronic pressure control in the constant flow mode was used. The internal standard (heptadecanoic acid, C17:0) and calibration standards (NuCheck, Elysian, $\mathrm{MN}$ ) were used for quantitation of fatty acids in the lipid extracts. The fatty acids reported represent the average of three determinations.

\section{Determination of antinutrient/phytochemical composition of therapeutic food}

Phytic acid was determined using the modified method of Ijarotimi et al. (2019). Tannin contents were determined using the modified vanillin- $\mathrm{HCl}$ methods (Jaffe 2003). Oxalate was determined by AOAC (2012) method. Meanwhile, trypsin inhibition activity was assayed according to the method of Kakade et al. (1974). The concentration of total phenolic content was determined using the Folin-Ciocalteu method described by Magalhães et al. (2010), with some modifications. The total flavonoid content of food samples was determined by the aluminium chloride colorimetric method (Chang et al. 2002). Total saponin content determination was subjected to gas chromatography-mass spectrometer (GCMS) analysis (Thenmozhi and Rajan 2015).

\section{Evaluation of functional properties of therapeutic food}

The water absorption and oil absorption capacities (WAC and $\mathrm{OAC}$ ) were determined as described by Onwuka and Onwuka (2005). The bulk density was determined as described by Trabelsi and Nelson (2006). The swelling index of the samples was determined as described by Alawode et al. (2017). The least gelation concentration of the food samples was determined as described by Sathe et al. (1982).

\section{Determination of antioxidant activities of therapeutic food}

Preparation of therapeutic food aqueous extracts: The food sample flour $(500 \mathrm{~g})$ was defatted and extracted exhaustively via maceration for $48 \mathrm{~h}$. with $2.5 \mathrm{~L}$ of distilled water. After maceration, the mixture was filtered (Muslin cloth and Whatman No.1 filter paper, Qualitative Circles $150 \mathrm{~mm}$ Cat No. 1001 150); and the filtrate was concentrated (Rotary evaporator; Model 349/2, Corning Limited) at $35^{\circ} \mathrm{C}$ for $24 \mathrm{~h}$. and thereafter, the filtrate was freeze-dried and the dried extract was stored $\left(\sim 27{ }^{\circ} \mathrm{C}\right)$ until required for use. The antioxidant activities of the therapeutic food samples were evaluated includes the ferric reducing antioxidant power (FRAP) assay which was performed as described by Benzie and Strain (1996) with some modifications. The chelating activity of the extract on $\mathrm{Fe}^{2+}$ was measured according to the method of Nehir and Karakaya (2004), with some modifications. The scavenging activity of therapeutic foods against 2, 2'-azinobis-3-ethylbenzthiazoline-6-sulphonic acid (ABTS) was 
determined according to the method described by $\mathrm{Re}$ et al. (1999) with slight modifications. Hydroxyl (OH) Free Radicals scavenging activity was determined according to the method reported by Klein et al. (1981).

\section{Evaluation of sensory attributes of therapeutic food}

The sensory evaluation of the therapeutic foods samples was conducted in a sensory laboratory with adequate lighting and no odour. Thirty (30) semi-trained panelists who were familiar with the control sample (OG, 100\% sorghum) were selected for the study. The therapeutic foods were constituted by stirring the flour samples in boiling water $(1: 4, \mathrm{w} / \mathrm{v})$ at $100{ }^{\circ} \mathrm{C}$ for $5 \mathrm{~min}$. The reconstituted therapeutic foods samples and the control food sample were coded and presented to the panelists. The panelists were assigned individually to laboratory booths and the constituted therapeutic foods and control were served at $40{ }^{\circ} \mathrm{C}$. Water was provided for mouth rinsing in between successive evaluations. The therapeutic foods sample attributes (colour, aroma, taste, texture, overall acceptability) were rated on a Hedonic scale of 1-9, where $1=$ dislike extremely and $9=$ like extremely (Olapade and Umeonuorah 2014).

\section{Statistical analysis}

Data were subjected to analysis of variance using SPSS (IBM version. 20.0, SPSS Inc., Quarry Bay, Hong Kong). The results were presented as means $( \pm S D)$.
Comparisons between means were done using Analysis of Variance (ANOVA) and Duncan's Multiple Range Test (DMRT). Values of $p<0.05$ were considered as statistically significant.

\section{Results}

\section{Proximate composition of therapeutic food}

The macronutrient and mineral composition of developed complementary foods are presented in Table 2. The crude protein, fat, carbohydrate and energy values of the food products varied from 16.16 to $16.93 \mathrm{~g} / 100 \mathrm{~g}, 13.12$ to $23.13 \mathrm{~g} / 100 \mathrm{~g}, 49.56$ to $58.81 \mathrm{~g} / 100 \mathrm{~g}$ and 418.08 to $474.13 \mathrm{kcal} . / 100 \mathrm{~g}$, respectively. The values were significantly $(p<0.05)$ higher than OG $(100 \%$ sorghum flour, a local complementary food), but significantly lower than Read-to-eat therapeutic food (P0). However, the study showed that crude protein, fat, and energy values in P1 were significantly $(p<0.05)$ higher than in P2 and P3, respectively. This view could be ascribed to inclusion of full-fat milk in P1, which was substituted with soycake flour in P2 and P3.

\section{Mineral composition of therapeutic food}

The mineral elements $(\mathrm{mg} / 100 \mathrm{~g})$ in developed complementary foods were K (4175-6350.5), Ca (341.5-949), Fe (23.5-50.5) Zn (28-38.5), P (3855.6-4501), and $\mathrm{Na}$ (343.5-950.5), and these values were significantly lower than in P0, but higher for K, Fe and Zn than in OG. The

Table 2 Proximate composition (\%), mineral (mg/100 g) and energy value (kcal/100 g) of therapeutic complementary foods

\begin{tabular}{|c|c|c|c|c|c|c|}
\hline Sample & OG & $\mathrm{P}_{0}$ & $P_{1}$ & $P_{2}$ & $P_{3}$ & ${ }^{*} \mathrm{RDA}$ \\
\hline Moisture & $7.26 \pm 0.03^{\mathrm{a}}$ & $4.90 \pm 0.01^{\mathrm{e}}$ & $5.36 \pm 0.02^{d}$ & $5.69 \pm 0.05^{c}$ & $6.26 \pm 0.04^{b}$ & - \\
\hline Crude fat & $4.83 \pm 0.01^{e}$ & $34.64 \pm 0.04^{\mathrm{a}}$ & $23.13 \pm 0.01^{b}$ & $20.0 \pm 0.02^{c}$ & $13.12 \pm 0.01^{d}$ & - \\
\hline Crude fibre & $2.09 \pm 0.02^{d}$ & $1.44 \pm 0.01^{e}$ & $2.67 \pm 0.01^{c}$ & $2.72 \pm 0.02^{b}$ & $2.82 \pm 0.02^{\mathrm{a}}$ & - \\
\hline Ash & $2.00 \pm 0.15^{c}$ & $2.00 \pm 0.26^{c}$ & $2.30 \pm 0.15^{b}$ & $2.75 \pm 0.02^{\mathrm{a}}$ & $2.78 \pm 0.01^{\mathrm{a}}$ & - \\
\hline Crude protein & $7.72 \pm 0.02^{e}$ & $17.47 \pm 0.03^{\mathrm{a}}$ & $16.93 \pm 0.01^{b}$ & $16.33 \pm 0.02^{c}$ & $16.16 \pm 0.00^{d}$ & 14 \\
\hline Carbohydrate & $76.09 \pm 0.32^{a}$ & $39.54 \pm 0.15^{\mathrm{e}}$ & $49.56 \pm 0.22^{d}$ & $52.41 \pm 0.11^{c}$ & $58.84 \pm 0.32^{b}$ & - \\
\hline Energy & $378.71 \pm 3.23^{e}$ & $539.8 \pm 4.11^{a}$ & $474.13 \pm 3.21^{b}$ & $454.96 \pm 2.45^{c}$ & $418.08 \pm 3.31^{d}$ & 765 \\
\hline Potassium & $1161.5 \pm 1.50^{\mathrm{e}}$ & $3072.5 \pm 2.50^{d}$ & $4175 \pm 0.50^{c}$ & $5150.0 \pm 0.30^{b}$ & $6350.50 \pm 0.50^{\mathrm{a}}$ & 3000 \\
\hline Calcium & $1164.5 \pm 1.50^{\mathrm{a}}$ & $1129.5 \pm 4.50^{b}$ & $949.0 \pm 1.00^{c}$ & $494.0 \pm 1.00^{d}$ & $341.5 \pm 1.50^{e}$ & 400 \\
\hline Iron & $0.90 \pm 0.02^{e}$ & $53.00 \pm 1.00^{\mathrm{a}}$ & $50.50 \pm 0.50^{b}$ & $27.00 \pm 0.03^{c}$ & $23.50 \pm 0.50^{d}$ & 4.5 \\
\hline Zinc & $20.00 \pm 0.03^{e}$ & $114.5 \pm 0.50^{\mathrm{a}}$ & $38.50 \pm 1.50^{b}$ & $30.00 \pm 1.00^{c}$ & $28.00 \pm 0.05^{d}$ & 1.6 \\
\hline Phosphorous & $4447.3 \pm 1.34^{c}$ & $4581.0 \pm 1.10^{\mathrm{a}}$ & $4501 \pm 1.15^{b}$ & $4443.1 \pm 1.05^{d}$ & $3855.6 \pm 1.70^{\mathrm{e}}$ & 460 \\
\hline Sodium & $1164.5 \pm 1.50^{\mathrm{a}}$ & $1149.5 \pm 0.05^{b}$ & $950.50 \pm 0.05^{c}$ & $495.00 \pm 0.40^{d}$ & $343.5 \pm 0.50^{\mathrm{e}}$ & 1000 \\
\hline $\mathrm{Na} / \mathrm{K}$ ratio & $1.71 \pm 0.01^{\mathrm{a}}$ & $0.64 \pm 0.01^{c}$ & $0.39 \pm 0.02^{d}$ & $0.16 \pm 0.01^{e}$ & $0.92 \pm 0.02^{b}$ & $<1.0$ \\
\hline $\mathrm{Ca} / \mathrm{P}$ ratio & $0.20 \pm 0.01^{\mathrm{a}}$ & $0.19 \pm 0.02^{\mathrm{a}}$ & $0.16 \pm 0.02^{b}$ & $0.09 \pm 0.01^{c}$ & $0.07 \pm 0.02^{c}$ & $>1.0$ \\
\hline
\end{tabular}

Values are mean of three determinations \pm standard deviation $(n=3)$. Values with the different superscript within the same row are significantly different from each other $(p \leq 0.05)$

*RDA (mg/day) (PAHO 2020)

Keys: P0 = Full fat milk $30 \%$, peanut $25 \%$, soybean oil $15 \%$, sugar $28 \%$, mineral mix $2 \%$, P1=Orange-fleshed sweet potato $26.5 \%$, sorghum $26.5 \%$, full fat milk $30 \%$, soybean oil $5 \%$, sugar $10 \%$, moringa leaves $2 \%$ ), P2 = Soycake $15 \%$, Orange fleshed sweet potato $26.5 \%$, sorghum $26.5 \%$, full fat milk $15 \%$, soybean oil $5 \%$, sugar $10 \%$, moringa leaves $2 \%$, P3 = Soycake $30 \%$, Orange fleshed sweet potato $26.5 \%$, sorghum $26.5 \%$, soybean oil $5 \%$ sugar $10 \%$, moringa leaves $2 \%$ ) and OG (100\% sorghum) 
observed variation in mineral elements of these products could be attributed to blending food materials and concentration.

\section{Amino acid profile of therapeutic food}

The amino acid profile of the developed complementary foods is presented in Table 3. The non-essential amino acids, the total values for developed complementary foods varied from 50.14 to $54.57 \mathrm{~g} / 100 \mathrm{~g}$ protein, while OG and P0 were 55.58 and $53.41 \mathrm{~g} / 100 \mathrm{~g}$ protein, respectively. Glutamic acid had the highest concentration of the non-essential amino acids with values range from 12.75 to $13.64 \mathrm{~g} / 100 \mathrm{~g}$ protein in P1 and P3,

Table 3 Amino acid profile (g/100 g protein) of therapeutic complementary foods

\begin{tabular}{|c|c|c|c|c|c|c|}
\hline Samples & OG & Po & P1 & P2 & P3 & ${ }^{*} \mathrm{RV}$ \\
\hline \multicolumn{7}{|c|}{ Non-essential amino acids (NEAAs) } \\
\hline Glycine & $4.67^{b}$ & $5.71^{a}$ & $3.69^{e}$ & $4.18^{d}$ & $4.33^{c}$ & - \\
\hline Alanine & $6.54^{\mathrm{a}}$ & $2.86^{\mathrm{e}}$ & $5.46^{d}$ & $5.52^{c}$ & $6.38^{b}$ & - \\
\hline Serine & $7.14^{\mathrm{a}}$ & $4.12^{e}$ & $5.77^{d}$ & $5.99^{c}$ & $6.32^{b}$ & - \\
\hline Proline & $4.86^{\mathrm{a}}$ & $3.03^{e}$ & $4.11^{d}$ & $4.27^{c}$ & $4.49^{b}$ & - \\
\hline Aspartic & $9.30^{a}$ & $8.64^{b}$ & $8.11^{d}$ & $8.20^{c}$ & $8.65^{b}$ & - \\
\hline Cysteine & $0.46^{b}$ & $1.97^{\mathrm{a}}$ & $0.37^{e}$ & $0.40^{d}$ & $0.44^{c}$ & - \\
\hline Glutamic & $13.96^{\mathrm{a}}$ & $11.85^{\mathrm{e}}$ & $12.75^{d}$ & $13.40^{c}$ & $13.64^{b}$ & - \\
\hline Threonine & $4.46^{\mathrm{a}}$ & $4.42^{b}$ & $3.54^{d}$ & $3.60^{c}$ & $3.40^{e}$ & - \\
\hline Tyrosine & $2.96^{b}$ & $3.90^{\mathrm{a}}$ & $2.37^{d}$ & $2.36^{d}$ & $2.79^{c}$ & - \\
\hline Arginine & $4.23^{b}$ & $6.91^{\mathrm{a}}$ & $3.97^{d}$ & $4.12^{c}$ & $4.13^{c}$ & - \\
\hline$\Sigma$ NEAAs & $58.58^{a}$ & $53.41^{c}$ & $50.14^{e}$ & $52.04^{d}$ & $54.57^{b}$ & - \\
\hline \multicolumn{7}{|l|}{ Essential amino acids (EAAs) } \\
\hline Phenylalanine & $4.44^{b}$ & $5.97^{\mathrm{a}}$ & $3.25^{e}$ & $3.33^{d}$ & $3.51^{c}$ & 6.90 \\
\hline Histidine & $1.89^{b}$ & $2.82^{\mathrm{a}}$ & $1.84^{c}$ & $1.84^{c}$ & $1.86^{c}$ & 1.00 \\
\hline Methionine & $2.17^{a}$ & $2.51^{c}$ & $1.88^{\mathrm{e}}$ & $2.01^{d}$ & $2.16^{b}$ & 2.70 \\
\hline Threonine & $4.46^{\mathrm{a}}$ & $4.42^{b}$ & $3.54^{d}$ & $3.60^{c}$ & $3.40^{\mathrm{e}}$ & 3.70 \\
\hline Valine & $4.23^{\mathrm{a}}$ & $3.59^{c}$ & $3.22^{e}$ & $3.52^{d}$ & $3.82^{b}$ & 3.80 \\
\hline Tryptophan & $1.04^{b}$ & $2.25^{\mathrm{a}}$ & $0.93^{d}$ & $0.94^{d}$ & $1.00^{c}$ & 1.25 \\
\hline Isoleucine & $3.51^{b}$ & $3.59^{\mathrm{a}}$ & $3.17^{e}$ & $3.31^{d}$ & $3.44^{c}$ & 3.10 \\
\hline Leucine & $6.64^{b}$ & $7.56^{\mathrm{a}}$ & $5.67^{d}$ & $5.93^{e}$ & $6.31^{c}$ & 7.30 \\
\hline Lysine & $4.48^{\mathrm{a}}$ & $4.45^{b}$ & $3.57^{d}$ & $3.84^{c}$ & $3.84^{c}$ & 6.40 \\
\hline$\sum E A A s$ & $28.40^{b}$ & $32.74^{\mathrm{a}}$ & $23.53^{e}$ & $24.72^{d}$ & $25.94^{c}$ & \\
\hline \multicolumn{7}{|c|}{ Predicted nutritional qualities } \\
\hline $\mathrm{TEAA}+\mathrm{His}+\mathrm{Arg} / \mathrm{TAA} \%$ & $44.82^{b}$ & $54.43^{\mathrm{a}}$ & $44.63^{c}$ & $44.66^{c}$ & $43.88^{d}$ & \\
\hline TEAA/TAA\% & $37.78^{b}$ & $43.13^{\mathrm{a}}$ & $36.74^{d}$ & $36.89^{c}$ & $36.44^{e}$ & \\
\hline TNEAA/TAA\% & $62.22^{d}$ & $56.87^{e}$ & $63.26^{b}$ & $63.11^{c}$ & $63.56^{a}$ & \\
\hline TSAA(Meth + Cys) & $2.63^{b}$ & $4.48^{a}$ & $2.25^{d}$ & $2.41^{c}$ & $2.60^{b}$ & \\
\hline ArEAA (Phe + Tyr) & $7.40^{b}$ & $9.87^{\mathrm{a}}$ & $5.62^{e}$ & $5.69^{d}$ & $6.30^{c}$ & \\
\hline TEAA/TNEAA & $0.61^{b}$ & $0.76^{\mathrm{a}}$ & $0.58^{c}$ & $0.59^{c}$ & $0.57^{c}$ & \\
\hline PER (g/100 g) & $2.19^{b}$ & $2.63^{\mathrm{a}}$ & $1.81^{e}$ & $1.90^{\mathrm{d}}$ & $1.96^{\mathrm{C}}$ & \\
\hline EAAI $(\%)$ & $62.03^{b}$ & $72.69^{a}$ & $52.94^{e}$ & $59.85^{c}$ & $56.72^{d}$ & \\
\hline P-BV (\%) & $55.91^{b}$ & $67.53^{\mathrm{a}}$ & $46.00^{e}$ & $53.53^{c}$ & $50.13^{d}$ & \\
\hline Nutritional index (\%) & $4.79^{e}$ & $12.70^{\mathrm{a}}$ & $8.96^{d}$ & $9.77^{b}$ & $9.17^{c}$ & \\
\hline Arginine/lysine & $0.94^{d}$ & $1.55^{\mathrm{a}}$ & $1.11^{b}$ & $1.07^{c}$ & $1.08^{c}$ & \\
\hline BCAAs & $14.38^{b}$ & $14.74^{\mathrm{a}}$ & $12.06^{\mathrm{e}}$ & $12.76^{d}$ & $13.57^{c}$ & \\
\hline
\end{tabular}

Mean values with the different superscript within the same row are significantly different from each other $(p \leq 0.05)$

Keys: P0 = Full fat milk $30 \%$, peanut $25 \%$, soybean oil $15 \%$, sugar $28 \%$, mineral mix $2 \%$, P1 = Orange-fleshed sweet potato $26.5 \%$, sorghum $26.5 \%$, full fat milk $30 \%$, soybean oil $5 \%$, sugar $10 \%$, moringa leaves $2 \%$ ); P2 = Soycake $15 \%$, Orange fleshed sweet potato $26.5 \%$, sorghum $26.5 \%$, full fat milk $15 \%$, soybean oil $5 \%$, sugar $10 \%$, moringa leaves $2 \%$; P3 = Soycake $30 \%$, Orange fleshed sweet potato $26.5 \%$, sorghum $26.5 \%$, soybean oil $5 \%$, sugar $10 \%$, moringa leaves $2 \%$ ) and OG (100\% sorghum); $\mathrm{BCAAs}=$ Branch chain amino acids (Valine + Isoleucine + leucine); $\mathrm{P}-\mathrm{BV}=$ Predicted biological value; $E A A I=E s s e n t i a l$ amino acid index; $\mathrm{PER}=\mathrm{Protein}$ efficiency ratio; ArEAA $=$ Aromatic amino acids (Phenylalanine + Tyrosine); TSAA $=$ Sulphur containing amino acids (Methionine + Cysteine); ${ }^{*}$ RV $($ WHO/FAO 2004) 
respectively, while those of OG and P0 were 13.96 and $11.85 \mathrm{~g} / 100 \mathrm{~g}$ protein, respectively.

For the essential amino acids, the concentrations in developed complementary foods were 23.53, 24.72 and $25.94 \mathrm{~g} / 100 \mathrm{~g}$ protein for P1, P2 and P3, while that of OG and $\mathrm{P} 0$ were 28.40 and $32.74 \mathrm{~g} / 100 \mathrm{~g}$ protein, respectively. The predicted protein efficiency ratios of the developed complementary foods ranged from 1.81 to 1.96 , and were lower than 2.19 and 2.63 for OG and P0, respectively. For the predicted biological value and essential amino acid index, the developed complementary foods, that is, P2 $(53.53 \%, 59.85 \%)$ had the highest values, while P1 $(46.0 \%$, $52.94 \%)$ had the lowest, and these values were comparatively lower than P0 (67.53\%, 72.69\%), OG (55.91\%, $62.03 \%)$, and recommended value $(>70 \%)$.

\section{Fatty acids profile of therapeutic food}

The fatty acid compositions of the complementary foods are shown in Table 4. Total saturated fatty acid (SFA) of the developed complementary foods ranged from 19.73\% in P1 to 20.61 in P2, and were higher than P0, but lower compared to OG. For monounsaturated fatty acids (MUFA) and polyunsaturated fatty acids (PUFA), the values ranged from 45.53 to $46.86 \%$ and 32.91 to $34.66 \%$, respectively. In MUFA and PUFA, oleic acid (44.21-44.97\%) and linolenic acid (23.21-24.57\%) were present in abundant concentration, respectively, and were comparatively higher than other fatty acids. The P/S $(\mathrm{P}=\mathrm{PUFA}+\mathrm{MUFA})$ ratio ranged from 3.95 to 6.23 , and were higher than OG (2.25), but comparable to P0 (4.26).

\section{Antinutrient/phytochemical composition of therapeutic food}

The antinutritional composition of developed complementary foods is presented in Table 5. The flavonoid, tannin, phenol and trypsin concentration in the formulated complementary food samples varied from 3.75 to $7.50 \mathrm{mg} / \mathrm{g}, 2.55$ to $2.86 \mathrm{mg} / \mathrm{g}, 29.63$ to $38.96 \mathrm{mg} / \mathrm{g}$ and 1.58 to $3.02 \mathrm{mg} / \mathrm{g}$, respectively. While saponin, oxalate and phytic acid concentration were $10.10-24.16 \%$, $18.47-19.54 \%$, and $30.07-39.65 \%$, respectively. The Phytate to iron (Phy:Fe) ratios of the formulated complementary foods varied from 0.051 to 0.143 , and the ratios were comparatively lower than OG (100\% sorghum flour) (2.602) and critical value $(>0.15)$, but within the value of P0 (0.041). The molar ratios of phytate to calcium (Phy:Ca) varied from 0.001 to 0.007 , and the ratios were lower than critical molar ratio of $[\mathrm{Phy}]$ : $[\mathrm{Ca}]<0.24$. The molar ratios of phytate to zinc of the developed complementary foods varied from 0.077 to 0.139 , and the values were lower than in OG (0.136) and P0 (0.221). The Oxalate/calcium $(\mathrm{Ox}: \mathrm{Ca}$ ) ratio of the formulated diets varied from 0.019 to 0.057 , and the values were similar to
Table 4 Fatty acid profile (\%) of therapeutic complementary foods

\begin{tabular}{|c|c|c|c|c|c|}
\hline Samples & OG & PO & P1 & P2 & P3 \\
\hline \multicolumn{6}{|c|}{ Saturated fatty acids (SFA) } \\
\hline Caprylic acid & $0.00^{\mathrm{a}}$ & $0.00^{\mathrm{a}}$ & $0.00^{\mathrm{a}}$ & $0.00^{\mathrm{a}}$ & $0.00^{\mathrm{a}}$ \\
\hline Capric acid & $0.00^{\mathrm{a}}$ & $0.00^{\mathrm{a}}$ & $0.00^{\mathrm{a}}$ & $0.00^{\mathrm{a}}$ & $0.00^{\mathrm{a}}$ \\
\hline Lauric acid & $0.00^{\mathrm{a}}$ & $0.00^{\mathrm{a}}$ & $0.00^{\mathrm{a}}$ & $0.00^{\mathrm{a}}$ & $0.00^{\mathrm{a}}$ \\
\hline Myristic acid & $0.32^{c}$ & $0.32^{c}$ & $0.36^{b}$ & $0.31^{c}$ & $0.76^{\mathrm{a}}$ \\
\hline Palmitic acid & $25.89^{\mathrm{a}}$ & $13.10^{b}$ & $12.21^{\mathrm{e}}$ & $12.77^{c}$ & $12.55^{\mathrm{d}}$ \\
\hline Margaric acid & $0.05^{b}$ & $0.05^{b}$ & $0.06^{b}$ & $0.05^{b}$ & $0.12^{\mathrm{a}}$ \\
\hline Stearic acids & $3.62^{d}$ & $4.13^{c}$ & $6.14^{\mathrm{a}}$ & $6.15^{\mathrm{a}}$ & $5.32^{b}$ \\
\hline Behenic acid & $0.52^{c}$ & $0.51^{c}$ & $0.58^{b}$ & $0.49^{c}$ & $1.25^{\mathrm{a}}$ \\
\hline Lignoceric acid & $0.07^{\mathrm{b}}$ & $0.07^{b}$ & $0.08^{b}$ & $0.07^{b}$ & $0.18^{a}$ \\
\hline Arachidic acid & $0.27^{b}$ & $0.08^{c}$ & $0.03^{d}$ & $0.77^{\mathrm{a}}$ & $0.00^{\mathrm{e}}$ \\
\hline$\Sigma S F A$ & $30.74^{\mathrm{a}}$ & $18.98^{\mathrm{e}}$ & $19.73^{d}$ & $20.61^{b}$ & $20.18^{c}$ \\
\hline \multicolumn{6}{|c|}{ Monounsaturated fatty acids (MUFA) } \\
\hline Palmitoleic acid & $1.40^{\mathrm{a}}$ & $0.80^{d}$ & $0.90^{c}$ & $0.77^{e}$ & $0.95^{b}$ \\
\hline Oleic acid & $24.25^{e}$ & $46.15^{\mathrm{a}}$ & $44.21^{d}$ & $44.40^{c}$ & $44.97^{b}$ \\
\hline Erucic acid & $0.38^{c}$ & $0.37^{c}$ & $0.43^{b}$ & $0.36^{c}$ & $0.91^{\mathrm{a}}$ \\
\hline$\Sigma$ MUFA & $26.03^{d}$ & $47.32^{\mathrm{a}}$ & $45.54^{c}$ & $45.53^{c}$ & $46.83^{b}$ \\
\hline \multicolumn{6}{|c|}{ Polyunsaturated fatty acids (PUFA) } \\
\hline Linoleic acid & $39.83^{\mathrm{a}}$ & $25.34^{b}$ & $23.21^{\mathrm{e}}$ & $24.37^{d}$ & $24.57^{c}$ \\
\hline Linolenic acid & $3.24^{e}$ & $8.21^{c}$ & $11.35^{\mathrm{a}}$ & $9.57^{b}$ & $8.13^{\mathrm{d}}$ \\
\hline Arachidonic acid & $0.09^{b}$ & $0.09^{b}$ & $0.10^{b}$ & $0.08^{b}$ & $0.21^{\mathrm{a}}$ \\
\hline$\Sigma$ PUFA & $43.16^{\mathrm{a}}$ & $33.64^{c}$ & $34.66^{b}$ & $34.02^{d}$ & $32.91^{\mathrm{e}}$ \\
\hline MUFA/PUFA & $0.60^{c}$ & $1.40^{\mathrm{a}}$ & $1.31^{\mathrm{b}}$ & $1.33^{b}$ & $1.42^{\mathrm{a}}$ \\
\hline PUFA/SFA & $1.40^{\mathrm{d}}$ & $1.77^{\mathrm{b}}$ & $1.75^{\mathrm{b}}$ & $3.95^{\mathrm{a}}$ & $1.63^{c}$ \\
\hline$(P U F A+M U F A) / S F A$ & $2.25^{\mathrm{e}}$ & $4.26^{b}$ & $4.06^{c}$ & $6.23^{\mathrm{a}}$ & $3.95^{\mathrm{d}}$ \\
\hline
\end{tabular}

Mean values with the different superscript within the same row are significantly different from each other $(p \leq 0.05)$

Keys: $\mathrm{PO}=$ Full fat milk $30 \%$, peanut $25 \%$, soybean oil $15 \%$, sugar $28 \%$, mineral mix $2 \%, \mathrm{P} 1=$ Orange-fleshed sweet potato $26.5 \%$, sorghum $26.5 \%$, full fat milk $30 \%$, soybean oil $5 \%$, sugar $10 \%$, moringa leaves $2 \%$ ), P2 = Soycake $15 \%$, Orange fleshed sweet potato $26.5 \%$, sorghum $26.5 \%$, full fat milk $15 \%$, soybean oil $5 \%$, sugar $10 \%$, moringa leaves $2 \%, \mathrm{P3}=$ Soycake $30 \%$, Orange fleshed sweet potato $26.5 \%$, sorghum $26.5 \%$, soybean oil $5 \%$, sugar $10 \%$, moringa leaves $2 \%$ ) and OG (100\% sorghum)

control samples (i.e., $\mathrm{OG}=0.004 ; \mathrm{P} 0=0.017$ ). The value of [Ca][Phy]: [Zn] molar ratios of the formulated complementary foods ranged from 1.191 to 1.826 , and were lower than the critical molar ratio of [Ca] [Phy]: [Zn], that is, (0.5).

\section{Functional properties of therapeutic food}

The functional property of formulated complementary foods and controls is shown in Table 6. The results vary from 0.61 to $0.83 \mathrm{~g} / \mathrm{ml}, 124.2$ to $176.2 \mathrm{mg} / \mathrm{g}$, and 102.2 to $257.19 \mathrm{mg} / \mathrm{g}$ for bulk density, oil absorption capacity and water absorption capacity, respectively. For the least gelation and swelling capacity, the values ranged were $0-1 \%$ and $164.70-373.30 \%$, respectively. There was significant 
Table 5 Anti-nutritional composition and phytate/mineral molar ratios (mol $/ \mathrm{kg})$ of therapeutic complementary foods

\begin{tabular}{|c|c|c|c|c|c|}
\hline Sample & OG & PO & P1 & P2 & P3 \\
\hline Flavonoid (mg/g) & $8.22 \pm 0.87^{\mathrm{a}}$ & $4.37 \pm 0.54^{c}$ & $3.75 \pm 0.93^{c}$ & $7.50 \pm 0.93^{b}$ & $6.72^{b} \pm 0.71$ \\
\hline Tannin (mg/g) & $0.13 \pm 0.02^{d}$ & $2.47 \pm 0.55^{c}$ & $2.55 \pm 0.01^{c}$ & $2.78 \pm 0.80^{b}$ & $2.86 \pm 0.01^{\mathrm{a}}$ \\
\hline Phenol (mg/g) & $23.19 \pm 1.07^{\mathrm{e}}$ & $45.80 \pm 0.65^{\mathrm{a}}$ & $29.63 \pm 1.50^{c}$ & $38.96 \pm 0.59^{b}$ & $26.63 \pm 1.80^{d}$ \\
\hline Trypsin conc. (mg/g) & $0.66 \pm 0.01^{d}$ & $3.08 \pm 0.02^{\mathrm{a}}$ & $3.02 \pm 0.02^{b}$ & $3.04 \pm 0.03^{b}$ & $1.58 \pm 0.01^{c}$ \\
\hline Saponin (\%) & $30.46 \pm 0.12^{\mathrm{a}}$ & $2.66 \pm 0.02^{\mathrm{e}}$ & $10.10 \pm 0.02^{d}$ & $18.85 \pm 0.05^{c}$ & $24.16 \pm 0.03^{b}$ \\
\hline Oxalate (\%) & $4.50 \pm 0.02^{e}$ & $18.99 \pm 0.10^{c}$ & $18.47 \pm 0.07^{d}$ & $19.39 \pm 0.03^{b}$ & $19.54 \pm 0.02^{\mathrm{a}}$ \\
\hline Phytic (\%) & $27.60 \pm 2.06^{c}$ & $25.68 \pm 7.26^{c}$ & $30.09 \pm 2.05^{b}$ & $30.07 \pm 1.23^{b}$ & $39.65 \pm 1.65^{\mathrm{a}}$ \\
\hline Phytate/Ca & $0.001^{c}$ & $0.001^{c}$ & $0.002^{c}$ & $0.004^{b}$ & $0.007^{\mathrm{a}}$ \\
\hline Phytate/Zn & $0.136^{c}$ & $0.221^{\mathrm{a}}$ & $0.077^{e}$ & $0.099^{d}$ & $0.139^{b}$ \\
\hline Phytate/iron & $2.602^{\mathrm{a}}$ & $0.041^{\mathrm{e}}$ & $0.051^{d}$ & $0.094^{c}$ & $0.143^{b}$ \\
\hline Phytate ${ }^{*} \mathrm{Ca} / \mathrm{Zn}$ & $3.957^{b}$ & $6.237^{\mathrm{a}}$ & $1.826^{c}$ & $1.219^{d}$ & $1.191^{\mathrm{e}}$ \\
\hline Oxalate/Ca & $0.004^{e}$ & $0.017^{d}$ & $0.019^{c}$ & $0.039^{b}$ & $0.057^{\mathrm{a}}$ \\
\hline
\end{tabular}

Values are mean of three determinations \pm standard deviation $(n=3)$. Values with the different superscript within the same row are significantly different from each other $(p \leq 0.05)$

Keys: P0 = Full fat milk 30\%, peanut $25 \%$, soybean oil $15 \%$, sugar $28 \%$, mineral mix $2 \%$, P1 = Orange-fleshed sweet potato $26.5 \%$, sorghum $26.5 \%$, full fat milk $30 \%$, soybean oil $5 \%$, sugar $10 \%$, moringa leaves $2 \%$ ); P2 = Soycake $15 \%$, Orange fleshed sweet potato $26.5 \%$, sorghum $26.5 \%$, full fat milk $15 \%$, soybean oil $5 \%$, sugar $10 \%$, moringa leaves $2 \%$; P3 = Soycake $30 \%$, Orange fleshed sweet potato $26.5 \%$, sorghum $26.5 \%$, soybean oil $5 \%$, sugar $10 \%$, moringa leaves $2 \%$ ) and OG (100\% sorghum) $\left[\mathrm{Phy} / \mathrm{Ca}=>0.24 ; \mathrm{Phytate} / \mathrm{Fe}=>0.15 ; \mathrm{Phytate} / \mathrm{Zn}=>15 ;\right.$ Oxalate $\left./ \mathrm{Ca}=>1 ; \mathrm{Phy}{ }^{*} \mathrm{Ca} / \mathrm{Zn}=>200\right]$

*phytate: calcium > 0.24 (Morris and Ellis 1985), phytate: iron > 1 (Hallberg et al. 1989), phytate: zinc > 15 (Turnlund et al. 1984; Sandberg 1991), phytate: calcium/ zinc > 200 (Davies et al. 1985; Bindra, et al. 1986; Gibson 2006)

Table 6 Functional properties of therapeutic complementary foods

\begin{tabular}{|c|c|c|c|c|c|}
\hline Sample & OG & PO & P1 & P2 & P3 \\
\hline Bulk density ( $\mathrm{g} / \mathrm{ml}$ ) & $0.68 \pm 0.02^{b}$ & $0.83 \pm 0.03^{\mathrm{a}}$ & $0.61 \pm 0.01^{d}$ & $0.63 \pm 0.01^{c}$ & $0.66 \pm 0.01^{c}$ \\
\hline $\mathrm{OAC}(\mathrm{mg} / \mathrm{g})$ & $174.70 \pm 1.45^{\mathrm{a}}$ & $124.20 \pm 0.80^{b}$ & $175.10 \pm 0.90^{a}$ & $176.70 \pm 1.45^{a}$ & $176.20 \pm 1.02^{a}$ \\
\hline WAC (mg/g) & $203.30 \pm 1.00^{d}$ & $102.20 \pm 2.06^{\mathrm{e}}$ & $160.00 \pm 0.10^{c}$ & $201.30 \pm 0.81^{b}$ & $257.19 \pm 1.41^{a}$ \\
\hline Least gelation (\%) & $1.00 \pm 0.00^{a}$ & $1.00 \pm 0.00^{\mathrm{a}}$ & $1.00 \pm 0.00^{\mathrm{a}}$ & $1.00 \pm 0.00^{\mathrm{a}}$ & $1.00 \pm 0.00^{a}$ \\
\hline Swelling (\%) & $420.00 \pm 1.50^{a}$ & $164.70 \pm 0.90^{e}$ & $276.80 \pm 0.95^{d}$ & $291.90 \pm 1.55^{c}$ & $373.30 \pm 0.90^{b}$ \\
\hline
\end{tabular}

Values are mean of three determinations \pm standard deviation $(n=3)$. Values with the different superscript within the same row are significantly different from each other $(p \leq 0.05)$

Keys: P0 = Full fat milk $30 \%$, peanut $25 \%$, soybean oil $15 \%$, sugar $28 \%$, mineral mix $2 \%$, P1 = Orange-fleshed sweet potato $26.5 \%$, sorghum $26.5 \%$, full fat milk $30 \%$, soybean oil $5 \%$, sugar $10 \%$, moringa leaves $2 \%$ ); P2 = Soycake $15 \%$, Orange fleshed sweet potato $26.5 \%$, sorghum $26.5 \%$, full fat milk $15 \%$, soybean oil $5 \%$, sugar $10 \%$, moringa leaves $2 \%$; P3 = Soycake $30 \%$, Orange fleshed sweet potato $26.5 \%$, sorghum $26.5 \%$, soybean oil $5 \%$, sugar $10 \%$, moringa leaves $2 \%$ ) and OG (100\% sorghum) $O A C$ oil absorption capacity, WAC water absorption capacity

$(p<0.05)$ different between the developed complementary foods and control samples.

\section{Antioxidant activities of therapeutic food}

The antioxidant activity of formulated complementary foods is presented in Table 7. The antioxidant activity of formulated complementary foods ranged from 2.07 to $3.24 \%, 8.61$ to $9.87 \mathrm{mg} / \mathrm{g}, 21.6$ to $40.95 \%$ and 62.42 to $87.0 \%$ for DPPH, FRAP, Fe-chelation and $\mathrm{OH}$-free radicals, respectively, and were significantly $(p<0.05)$ higher than in OG and PO. Comparatively, the antioxidant activity of P2 against DPPH, FRAP, iron chelation and hydroxyl-free radicals had the highest activities than in P1 and P3, respectively. This observation could be ascribed to the synergistic property of food components in P2 (i.e., milk:soycake flour 1:1).

\section{Sensory attributes of therapeutic food}

The sensory qualities of formulated complementary foods are presented in Table 8 . The P1 sample was significantly $(p<0.05)$ rated highest in terms of appearance, aroma, taste, texture and overall acceptability followed by P2 and P3, respectively. However, the panelists rated the formulated complementary foods lower than OG and P0 in all the sensory attributes. 
Table 7 Antioxidant activities of therapeutic complementary foods

\begin{tabular}{|c|c|c|c|c|c|}
\hline SAMPLE & OG & PO & P1 & P2 & P3 \\
\hline DPPH (\%) & $1.99 \pm 0.01^{d}$ & $2.11 \pm 0.05^{c}$ & $2.07 \pm 0.03^{c}$ & $3.24 \pm 0.55^{\mathrm{a}}$ & $3.22 \pm 0.05^{b}$ \\
\hline FRAP (mg/g) & $4.24 \pm 0.02^{\mathrm{e}}$ & $6.39 \pm 0.04^{d}$ & $8.61 \pm 0.06^{c}$ & $9.87 \pm 0.02^{\mathrm{a}}$ & $9.53 \pm 0.02^{b}$ \\
\hline $\mathrm{Fe}^{2+}$ chelation (\%) & $6.91 \pm 3.14^{e}$ & $8.54 \pm 0.02^{d}$ & $21.60 \pm 0.03^{c}$ & $40.95 \pm 0.02^{\mathrm{a}}$ & $39.44 \pm 0.03^{b}$ \\
\hline $\mathrm{OH}(\%)$ & $8.47 \pm 1.13^{e}$ & $38.80 \pm 0.63^{d}$ & $62.42 \pm 0.84^{c}$ & $87.00 \pm 1.13^{\mathrm{a}}$ & $70.33 \pm 0.84^{b}$ \\
\hline ABTS (Mmol/g) & $0.01 \pm 0.00^{\mathrm{a}}$ & $0.01 \pm 0.00^{\mathrm{a}}$ & $0.01 \pm 0.00^{\mathrm{a}}$ & $0.02 \pm 0.00^{\mathrm{a}}$ & $0.01 \pm 0.00^{\mathrm{a}}$ \\
\hline
\end{tabular}

Values are mean of three determinations \pm standard deviation $(n=3)$. Values with the different superscript within the same row are significantly different from each other $(p \leq 0.05)$

Keys: P0 = Full fat milk $30 \%$, peanut $25 \%$, soybean oil $15 \%$, sugar $28 \%$, mineral mix $2 \%$, P1=Orange-fleshed sweet potato $26.5 \%$, sorghum $26.5 \%$, full fat milk $30 \%$, soybean oil $5 \%$, sugar $10 \%$, moringa leaves $2 \%$ ); P2 = Soycake $15 \%$, Orange fleshed sweet potato $26.5 \%$, sorghum $26.5 \%$, full fat milk $15 \%$, soybean oil $5 \%$, sugar $10 \%$, moringa leaves $2 \%$; P3 = Soycake $30 \%$, Orange fleshed sweet potato $26.5 \%$, sorghum $26.5 \%$, soybean oil $5 \%$, sugar $10 \%$, moringa leaves $2 \%$ ) and OG ( $100 \%$ sorghum)

Table 8 Sensory attributes of therapeutic complementary foods

\begin{tabular}{llllll}
\hline Sample & Appearance & Aroma & Taste & Texture & General acceptance \\
\hline OG & $8.15 \pm 1.03^{\mathrm{a}}$ & $7.45 \pm 1.39^{\mathrm{bc}}$ & $7.60 \pm 1.60^{\mathrm{b}}$ & $8.10 \pm 0.91^{\mathrm{a}}$ & $8.00 \pm 1.07^{\mathrm{a}}$ \\
P0 & $7.40 \pm 1.14^{\mathrm{c}}$ & $8.15 \pm 1.13^{\mathrm{b}}$ & $8.55 \pm 0.88^{\mathrm{a}}$ & $7.10 \pm 1.61^{\mathrm{c}}$ & $8.05 \pm 1.09^{\mathrm{b}}$ \\
P1 & $6.30 \pm 1.38^{\mathrm{b}}$ & $6.10 \pm 1.4^{\mathrm{c}}$ & $6.40 \pm 1.50^{\mathrm{a}}$ & $6.65 \pm 1.26^{\mathrm{bc}}$ & $6.80 \pm 0.89^{\mathrm{c}}$ \\
P2 & $6.61 \pm 1.93^{\mathrm{a}}$ & $5.55 \pm 1.57^{\mathrm{bc}}$ & $5.35 \pm 1.49^{\mathrm{c}}$ & $6.30 \pm 1.34^{\mathrm{bc}}$ & $6.05 \pm 1.09^{\mathrm{b}}$ \\
P3 & $5.75 \pm 1.44^{\mathrm{a}}$ & $4.80 \pm 1.36^{\mathrm{a}}$ & $4.35 \pm 1.08^{\mathrm{a}}$ & $6.00 \pm 1.41^{\mathrm{a}}$ & $5.50 \pm 1.35^{\mathrm{a}}$ \\
\hline
\end{tabular}

Values are mean of thirty panelists \pm standard deviation $(n=30)$. Values with the different superscript within the same row are significantly different from each other $(p \leq 0.05)$

Keys: P0 = Full fat milk $30 \%$, peanut $25 \%$, soybean oil $15 \%$, sugar $28 \%$, mineral mix $2 \%$, P1 = Orange-fleshed sweet potato $26.5 \%$, sorghum $26.5 \%$, full fat milk $30 \%$, soybean oil $5 \%$, sugar $10 \%$, moringa leaves $2 \%$ ); P2 = Soycake $15 \%$, Orange fleshed sweet potato $26.5 \%$, sorghum $26.5 \%$, full fat milk $15 \%$, soybean oil $5 \%$, sugar $10 \%$, moringa leaves $2 \%$; P3 = Soycake $30 \%$, Orange fleshed sweet potato $26.5 \%$, sorghum $26.5 \%$, soybean oil $5 \%$, sugar $10 \%$, moringa leaves $2 \%$ ) and OG (100\% sorghum)

\section{Discussion}

The formulated food products were appreciably high in protein content and were capable of providing over $100 \%$ of daily protein requirement of the infant compare to traditional complementary food (i.e., $100 \%$ sorghumbased, OG). This could be ascribed to the inclusion of soycake, milk and moringa leaves powder, which studies have reported to be high in protein (Shiriki et al. 2015; Mounika et al. 2021; Oluwajuyitan et al. 2021). The energy values of the food products were comparatively higher than traditional complementary food $(100 \%$ sorghum), but lower than that of control (P0, a UNICEF product). However, the formulated food products could provide above $50 \%$ of daily energy requirement of the infants. This finding agreed with previous reports that plant-based complementary foods is usually low in energy density (Shiriki et al. 2015; Adepoju and Ayenitaju 2021). Nutritionally, the higher protein and energy values of the present study food products could be advantageous over local complementary food from sorghum (ogi) in supporting growth and development in children. The traditional complementary foods in the developing countries are known to be of low nutritive value and are characterized by low protein, low energy density and high bulk, because they are usually unfortified cereal-based (Shiriki et al. 2015). The protein content of cereals such as sorghum, which is often used, is of poor quality, being low in lysine and tryptophan amino acids, which are indispensable for the growth of the young child (Shiriki et al. 2015). Hence, this local complementary food has been implicated as one of the major causes of severe acute malnutrition in children (Shiriki et al. 2015).

The essential mineral elements like $\mathrm{Ca}, \mathrm{Zn}$ and $\mathrm{Fe}$ in the developed food products were higher than their dailyrecommended values for children (i.e., $\mathrm{Ca}=105 \mathrm{mg} /$ day, $\mathrm{Zn}=1.6 \mathrm{mg} /$ day and $\mathrm{Fe}=4.5 \mathrm{mg} /$ day) (Oria et al. 2019). This implies that the formulated complementary foods were able to provide above $100 \%$ of recommended daily requirements for $\mathrm{Ca}, \mathrm{Fe}$ and $\mathrm{Zn}$, and this could be as a result of moringa powder that was used to fortify the food products. It is well established that moriga leaf is high in micronutrients like $\mathrm{Ca}, \mathrm{Fe}$, etc. (Shiriki et al. 2015; Mounika et al. 2021). The $\mathrm{Na} / \mathrm{K}$ and $\mathrm{Ca} / \mathrm{P}$ molar ratios of the developed food products ranged from 0.16 to 0.92 and 0.07 to 0.16 and were lower than P0 and OG, respectively. The lower value of $\mathrm{Na} / \mathrm{K}$ ratios in the formulated complementary food samples was lower than recommended value of $<1.0$; and this is beneficial, because it would not pose unnecessary stress on the immature heart of the infant, and thereby causing heart damage. However, the complementary food products were lower in $\mathrm{Ca} / \mathrm{P}$ ratio than recommended value of $>1$; and this 
indicates that the present food products may not sufficiently provide calcium requirement for the formation of teeth and bone of the children, hence, there may be needs for calcium supplement. Recently, studies have reported on deficiency of vital minerals like $\mathrm{Ca}$, Fe, etc. in traditional complementary foods, which have resulted into increase in micronutrient deficiency among children in many parts of developing countries (Ferguson et al. 2015; Abeshu et al. 2016). To address the menace, studies have advocated for adequate nutrition during the first to second year of life to ensure optimal physical and mental development of infants and young children (Abeshu et al. 2016).

The amino acid profile of the formulated food products showed that glutamic acid had the highest concentration, and this agreed with earlier reports that in plant-based foods glutamic acid is usually present in abundant compare to other amino acids (Aremu et al. 2006; Ijarotimi and Oluwalana 2013). The total essential amino acids of the products were significantly lower than control product (P0), and this could be attributed to the fact that the control sample was supplemented with full-fat milk, an animal product. Tryptophan and arginine that are particularly required for infants, and were abundantly present in the formulated complementary foods. These amino acids are required in infant for normal growth and development (Kim et al. 2007; Valentine et al. 2017). The biological value and essential amino acids index of the formulated complementary food were comparatively lower than that of control (P0). This is expected in the sense that P0 was enriched with full-fat milk, an animal food product. Besides, the disparity could be ascribed to the nature of food composition and amount of essential amino acids. It is well established that cereal-based and other plant-based complementary foods are low in protein, essential amino acids and biological values (Nout and Rombouts 1992; Ijarotimi and Keshinro 2012). Hence, they have failed to provide sufficient nutrients for the growth and development of infant and young children. Interestingly, this observation agreed with the report of Ijarotimi et al. (2018), who formulated diets from the combination of quality-protein-maize, soybean and moringa (seed and leaf) flour.

For the essential fatty acid composition, oleic and linolenic fatty acids were present in most abundant in the formulated food products. These fatty acids are particularly essential for the growth and development of children. The PUFA/SFA ratios of the food samples was higher than one $(>1)$. This indicates that the fatty acids in the food samples is higher in polyunsaturated fatty acids, which is highly beneficial to the children in that it would prevent formation of arteriosclerosis, and damaging to the heart. It is well established that intake of fatty acids (especially PUFA) enhances infant brain growth and development, immune system, and lower the risk of heart disease (Lee 2013).

The antinutrients in developed complementary foods were lower than critical values, and were comparable to the values obtained for control samples (OG and P0) and that of complementary foods formulated by Gemede (2020). The phytate:iron molar ratio $>0.15$ is indicative of poor iron bioavailability (Abizari et al. 2012). This indicates that the iron content in the present study complementary foods would be readily available; therefore would enhance blood formation and thereby preventing anaemia in children. The phytate/calcium molar ratio $>0.24$ indicates good calcium bioavailability (Woldegiorgis et al. 2015). This finding shows that the absorption and bioavailability of calcium in the formulated complementary foods in the present study is quite high. Hence, the food samples would enhance bone and teeth formation in children, and thereby preventing bone deformation like rickets. Foods with a molar ratio of Phy: $Z n<10$ showed adequate availability of zinc, while Phy: $\mathrm{Zn}$ molar ratios $>15$ is an indication of poor zinc bioavailability (Morris and Ellis 1985). Interestingly, these values in the formulated diets were lower than the critical molar ratios of Phy: Zn, which indicates high bioavailability of zinc. The bioavailability of dietary zinc might be reduced by phytate (Bhandari and Kawabata 2004). Hence, the Phy:Zn molar ratio is considered a better indicator of zinc bioavailability than total dietary phytate levels alone (Woldegiorgis et al. 2015).

From this study, finding shows that the Ox:Ca molar ratios of the complementary foods were lower than the reported critical value (1.0), which implies that oxalate cannot have any adverse effects on bioavailability of dietary calcium in these food samples. Oxalic acid and its salts can have deleterious effects on human nutrition and health, particularly by decreasing calcium absorption and aiding the formation of kidney stones (Bhandari and Kawabata 2004). The [Ca][Phy]:[Zn] molar ratio of the diets was lower than recommended critical values (>200). This indicates high bioavailability of zinc in all the formulated diets. Zinc plays major role in the diet of children, because it is required for the brain development and immune system. The potent effect of calcium on zinc absorption in the presence of high phytate intakes has led to the suggestion that the $[\mathrm{Phy}][\mathrm{Ca}] /[\mathrm{Zn}]$ millimolar ratio may be a better index of zinc bioavailability than the $[\mathrm{Phy}] /[\mathrm{Zn}]$ molar ratio alone (Frontela et al. 2009). High calcium levels in foods can promote interaction between phytate-zinc, and thereby decrease zinc bioavailability, particularly when the $[\mathrm{Ca}][\mathrm{Phy}]:[\mathrm{Zn}]$ millimolar ratio exceeds $0.5 \mathrm{~mol} / \mathrm{kg}$ (Adetuyi and Komolafe 2011). This finding is contrary to the belief that iron, 
calcium and zinc deficiency are common phenomenon in traditional complementary foods in developing countries particularly Africa (Ferguson et al. 2015), which normally requires external solutions, such as fortification to ensure adequate intakes.

Functional properties of the complementary foods are very important, particularly for the growing children (Omueti et al. 2009). The physical parameter of foods in terms of consistency of energy density (energy per unit volume) and frequency of feeding are the important factors in determining the extent to which children will meet their energy and nutrient requirements (Omueti et al. 2009). The bulk density of the formulated complementary foods was comparatively lower than that of sorghumbased (OG) and control samples (P0), and it is increased as the percentage of soycake inclusion increases. The low BD of formulated complementary foods indicates that gruel or porridge made from this diet will have a lower dietary bulk. This is desirable in complementary foods because loose bulk density enhances adequate energynutrient intake per feed and easy digestibility of complementary foods in children with small volume of stomach and immature digestive system (Osundahunsi and Aworh 2002; Ijarotimi and keshinro 2013). Apart from dietary bulk of the gruel or porridge made from these complementary diets, the low bulk density is also important in the packaging requirement and material handling of the complementary foods (Perez 1997). The loose pack density (LPD) is related to the bulk density, the higher the LPD the higher the bulk density. This is because the LPD indicates the free space between the foods when packed. A large free space is undesirable in packaging of foods because it constitute a large oxygen reservoir. Water absorption capacity (WAC) and oil absorption capacity $(\mathrm{OAC})$ of formulated diets were comparatively higher than control (P0). This may be attributed to the high protein content of the food samples, which is hydrophilic in nature and will make the diet to absorb and bind more water; and low fat content, which is hydrophobic in nature, and thereby restrict water absorption by forming amylose-lipid complex with the polysaccharide in the diet thus decreasing the amount of water absorbed (Otegbayo 2002). Besides, water absorption capacity (WAC) is an index of the maximum amount of water that a food product would absorb and retain (Adesanmi et al. 2020); and with low WAC the microbial activities of the food products would be reduced. Hence, the shelf-life of such food products would be extended.

The formulated complementary foods exhibited higher antioxidant activities against DPPH, FRAP, Fe-chelation and hydroxyl free radicals than traditional complementary food and control samples. This may be attributed to the food compositions, that is, soycake, sorghum and orange sweet flesh potato, which are plant-based, and with antioxidant properties. Interestingly, this observation agreed with Itagi and Singh (2012), who reported on the antioxidant activities of multigrain composite flour blends. In recent decades, natural antioxidants have attracted considerable interest among nutritionists, food manufacturers and consumers, due to their presumed safety and potential therapeutic value (Sreeramulu et al 2009). Studies have established that several human diseases are caused by oxidative stress that results from imbalance between the formation and neutralization of pro-oxidants (Hazra et al. 2008). Oxidative stress initiated by free radicals, such as superoxide anions, hydrogen peroxide, hydroxyl, nitric oxide and peroxynitrite, have been implicated to play vital roles in damaging various cellular macromolecules leading to dysfunction of many organs (Polterat 1997). However, consumption of foods rich in antioxidant may prevent malfunctioning of cells and occurrence of chronic diseases.

Overall acceptability of the formulated complementary foods were significantly $(p<0.05)$ rated lower when compared to $100 \%$ sorghum-based complementary food and control samples by the panelists. This could be attributed to the familiarity of the panelists and food composition of OG (100\% sorghum flour) and P0 (a ready-eat-therapeutic food produced by UNICEF). The P0 was most preferred in taste compared to formulated complementary foods, and this could be because of sugar which was added during formulation. Besides, it could have been due to inclusion of sweet potatoes flour into the formulated complementary foods, which mighty have imparted slight bitter taste due to the presence of ipomeamarone, which characterized with bitter taste due to heat application (Damian et al. 2018).

\section{Conclusions}

The formulated complementary foods in the present study were based on locally available low-cost food materials in Nigeria. The formulated complementary foods had enough nutrient compositions and energy values to meet the requirements for infants as recommended for complementary foods and for amelioration of severe acute malnutrition in children. Therefore, the formulated complementary foods are potentially suitable for use as complementary foods in Nigeria and other developing countries. Nutritional and sensory evaluation revealed that addition of full fat milk to P1 sample significantly improved its nutrient composition and organoleptic quality and contributed to its high acceptance compared to other formulations. The fact that these recipes are inexpensive, locally available and nutritious makes them potentially effective in solving some of the nutrition problems facing infants and children in Nigeria. 
However, biological studies are required to explore the possibility of improving locally formulated complementary foods for the management of protein-energy malnutrition (PEM).

\begin{abstract}
Abbreviations
PO: Full fat milk $30 \%$, peanut $25 \%$, soybean oil $15 \%$, sugar $28 \%$, mineral mix $2 \%$; P1: Orange-fleshed sweet potato $26.5 \%$, sorghum $26.5 \%$, full fat milk $30 \%$, soybean oil 5\%, sugar 10\%, moringa leaves 2\%; P2: Soycake $15 \%$, Orange fleshed sweet potato $26.5 \%$, sorghum $26.5 \%$, full fat milk $15 \%$, soybean oil $5 \%$, sugar $10 \%$, moringa leaves $2 \%$; P3: Soycake $30 \%$, Orange fleshed sweet potato $26.5 \%$, sorghum $26.5 \%$, soybean oil $5 \%$, sugar $10 \%$, moringa leaves $2 \%$; OG: 100\% Sorghum; BCAAs: Branch chain amino acids (Valine + Isoleucine + leucine); P-BV: Predicted biological value; EAAI: Essential amino acid index; PER: Protein efficiency ratio; MUFA: Monounsaturated fatty acids; PUFA: Polyunsaturated fatty acids; SFA: Saturated fatty acids; OAC: Oil absorption capacity; WAC: Water absorption capacity.
\end{abstract}

\section{Acknowledgements}

The authors would like to acknowledge the laboratory staff of the Department of Food Science and Technology, and Central Nutritional Laboratory, Federal University of Technology, Akure, Nigeria as well as UNICEF.

\section{Authors' contributions}

FMR collected sample and data, OTD analysed data and proof read the first draft as well served as the corresponding author of the manuscript while IOS designed the experiment, supervised the study, and proof read the final draft of the manuscript. The authors read and approved the final manuscript.

\section{Funding}

No funding was received for this research work.

\section{Availability of data and material}

Data are available on request.

\section{Declarations}

\section{Ethical approval and consent to participate}

The study protocol was approved by the Ethical Committee School of Agriculture and Agricultural Technology, Federal University of Technology, Akure, Nigeria (FUTA/SAAT/2020/019). Verbal consent to participate was obtained from the sensory panelist who participate in sensory evaluation.

\section{Consent for publication}

Not applicable.

\section{Competing interests}

The authors declare no competing interests.

Received: 20 August 2021 Accepted: 8 February 2022

Published online: 20 February 2022

\section{References}

Abeshu MA, Lelisa A, Geleta B (2016) Complementary feeding: review of recommendations, feeding practices, and adequacy of homemade complementary food preparations in developing countries-lessons from Ethiopia. Front Nutr. https://doi.org/10.3389/fnut.2016.00041

Abizari AR, Moretti D, Schuth S, Zimmermann MB, Armar-Klemesu M, Brouwer ID (2012) Phytic acid-to-iron molar ratio rather than polyphenol concentration determines iron bioavailability in whole-cowpea meal among young women. J Nutr 142(11):1950-1955

Adejuwon KP, Osundahunsi OF, Oluwajuyitan TD, Oluwamukomi MO (2021) Influence of fermentation on macro and micro nutrient of toddler formula. J Culin Sci Technol. https://doi.org/10.1080/15428052.2021. 1879337
Adepoju OT, Ayenitaju AO (2021) Assessment of acceptability and nutrient content of palm weevil (Rhyncophorus phoenicis) larvae enriched complementary foods. Int J Trop Insect Sci 1:1-14

Adesanmi AR, Malomo SA, Fagbemi TN (2020) Nutritional quality of formulated complementary diet from defatted almond seed, yellow maize and quality protein maize flours. Food Prod Proc Nutr. https://doi.org/10. 1186/s43014-020-00037-7

Adetuyi FO, Komolafe EA (2011) Effect of the addition of okra seed (Abelmoschus esculentus) flour on the antioxidant properties of plantain Musa paradisiaca flour. Annu Rev Res Biol 1(4):143-152

Alabi MO, Oluwatosin BC (2001) Creating awareness on utilization of soybean flour for baked products in the catering industry; a preliminary study of physical properties and acceptability of soy cake. Afr J Biotechnol 7(1):2623-2625

Alawode KE, Idowu MA, Adeola AA, Oke EK, Omoniyi SA (2017) Some quality attributes of complementary food produced from flour blends of orange flesh sweetpotato, sorghum, and soybean. Croat J Food Sci Technol 9(2):122-129

AOAC (2012) Official methods of analysis. 19th Ed. Association of Official Analytical Chemists International, Rockville, MD, USA

Aremu MO, Olaofe O, Akintayo ET (2006) Chemical composition and physicochemical characteristic of two varieties of Bambara groundnut (Vigna subterranean) flours. J Appl Sci. https://doi.org/10.3923/jas.2006.1900. 1903

Asibuo JY, Akromah R, Safo-Kantanka O, Adu-Dapaah HK, Ohemeng-Dapaah S, Agyeman A (2008) Chemical composition of groundnut, Arachis hypogaea (L.) landraces. Afr J Biotechnol 7(13):1-12

Atasie VN, Akinhanmi TF, Ojiodu CC (2009) Proximate analysis and physicochemical properties of groundnut (Arachis hypogaea L.). Pak J Nutr 8(2):194-197

Awopetu JA (2021) Comparative analysis of potential genetic nutritive value in three oil seed crops. Afri J Gen Agric 5(4):1-12

Azeem M, Mu TH, Zhang M (2020) Effects of high hydrostatic pressure and soaking solution on proximate composition, polyphenols, anthocyanins, $\beta$-carotene, and antioxidant activity of white, orange, and purple fleshed sweet potato flour. Food Sci Technol Int 26(5):388-402

Bailey-Shaw Y, Rodney S, Golding C, Foster S, Randle M, Watson C (2021) The potential applications of Moringa Oleifera leaves in functional herbal beverages: a review of its nutritional, medicinal, and toxicity profiles. Curr NutrFood Sci 17(3):272-287

Banaszkiewicz T (2011) Nutritional value of soybean meal. In: El-Shemy HA (ed) Soybean and nutrition, vol 1. Rijeka, InTech, pp 1-20

Barcus GC, Papathakis PC, Schaffner A, Chimera B (2021) Nutrition screening, reported dietary intake, hospital foods, and malnutrition in critical care patients in Malawi. Nutrients 13(4):1170

Benzie IF, Strain JJ (1996) The ferric reducing ability of plasma (FRAP) as a measure of "antioxidant power": the FRAP assay. Anal Biochem 239(1):70-76

Bhandari MR, Kawabata J (2004) Assessment of antinutritional factors and bioavailability of calcium and zinc in wild yam (Dioscorea spp.) tubers of Nepal. Food Chem 85(2):281-287

Bidlingmeyer BA, Cohen SA, Tarvin TL (1984) Rapid analysis of amino acids using pre-column derivatization. J Chromatograp B Biomed Sci Appl 336(1):93-104

Bindra GS, Gibson RS, Thompson LU (1986) [Phytate][calcium]/[zinc] ratios in Asian immigrant lacto-ovo vegetarian diets and their relationship to zinc nutriture. Nutr Res 6(5):475-483

Black RE, Allen LH, Bhutta ZA, Caulfield LE, de Onis M, Ezzati M, Rivera J (2008) Maternal and child undernutrition: global and regional exposures and health consequences. Lancet 371(9608):243-260

Boateng L, Nyarko R, Asante M, Steiner-Asiedu M (2018) Acceptability of complementary foods that incorporate Moringa oleifera leaf powder among infants and their caregivers. Food Nutr Bul 39(1):137-148

Campos R, Hernandez L, Soto-Mendez MJ, Vossenaar M, Solomons NW (2010) Contribution of complementary food nutrients to estimated total nutrient intakes for rural Guatemalan infants in the second semester of life. Asia Pac J Clin Nutr 19(4):481-490

Carral JM, García T, Sáez-Royuela M, Celada JD, Maraña L (2021) Growth and feed utilization of juvenile tench (Tinca tinca L.) given diets in which soy 
protein concentrate replaces fishmeal and methionine and arginine are used as amino acid supplements. J Appl Aquac 1:1-20

Chang CC, Yang MH, Wen HM, Chern JC (2002) Estimation of total flavonoid content in propolis by two complementary colometric methods. J Food Drug Anal 10(3):3-12

Chikpah SK, Korese JK, Hensel O, Sturm B (2020) Effect of sieve particle size and blend proportion on the quality properties of peeled and unpeeled orange fleshed sweet potato composite flours. Foods 9(6):7-40

Daelmans B, Saadeh R (2003) Global initiatives to improve complementary feeding. In: SCN Newsletter: meeting the challenge to improve complementary feeding. United Nations System Standing Committee on Nutrition. Moreira, AD. (ed) Lavenhem Press, UK, pp 10-17

Damian L, Faustina DW, Ibok O (2018) Formulation and characterization of sweetpotato-based complementary food. Cogent Food Agric. https://doi.org/10.1080/23311932.2018.1517426

Davies NT, Carswell AJP, Mills CF (1985) Effect of variation in dietary calcium intake on the phytate-zinc interaction in rats. In: Mills CF, Bremner I, Chesters JK, Farnham RS (eds) Trace elements in man and animals: TEMA 5: proceedings of the fifth international symposium on trace elements in man and animals. Commonwealth Agricultural Bureaux, C1985

Dean LL (2021) Peanut protein-processes and applications. A Review. J Nutr Food Sci 4(2):10-31

Dong H, Lu Y, Zhang Y, Mu S, Wang N, Du P, Guo H (2021) A heat-induced Mutation on VP1 of FMDV Serotype O Enhanced Capsid Stability and the Immunogenicity. J Virol 95:e0177-21

Duodu KG, Taylor JRN, Belton PS, Hamaker BR (2003) Factors affecting Sorghum protein digestibility. J Cereal Sci 38(2):117-131

El Nehir S, Karakaya S (2004) Radical scavenging and iron-chelating activities of some greens used as traditional dishes in Mediterranean diet. Int J Food Sci Nutr 55(1):67-74

Elemo GN, Elemo BO, Okafor JNC (2011) Preparation and nutritional composition of a weaning food formulated from germinated Sorghum (Sorghum bicolor) and steamed cooked cowpea (Vigna unguiculata Walp.). Am J Food Technol 6(1):413-421

Ferguson EL, Gibson RS, Thompson LU, Ounpuu S, Berry M (1988) Phytate, zinc, and calcium contents of 30 East African foods and their calculated phytate: Zn, Ca: phytate, and [Ca][phytate]/[Zn] molar ratios. J Food Compos Anal 1(4):316-325

Ferguson E, Chege P, Kimiywe J, Wiesmann D, Hotz C (2015) Zinc, iron and calcium are major limiting nutrients in the complementary diets of rural Kenyan children. Matern Child Nutr. https://doi.org/10.1111/ mcn. 12243

Frontela C, Ros G, Martínez C (2009) Effect of dephytinization on bioavailability of iron, calcium and from infant cereals assessed in the Caco-2 cell model. World J Gastroenterol 15(16):1977-1984

Gajmal DB, Pawar VS, Shinde EM, Shingote AB (2021) Effect of particle size based sorghum flour of physicochemical properties on sensory characteristics of roti prepared from Parbhani Moti and Parbhani Super Moti. Magnesium 290(2.30):249-250

Gbadebo CT, Ahmed LT (2021) Proximate composition and sensory evaluation of Guinea corn meal enriched with soybean and groundnut for infant feeding. Croat J Food Sci Technol 13(1):51-56

Gehrke CW, Wall LL Sr, Absheer JS, Kaiser FE, Zumwalt RW (1985) Sample preparation for chromatography of amino acids: acid hydrolysis of proteins. J Assoc Off Anal Chem 68(5):811-821

Gemede HF (2020) Nutritional and antinutritional evaluation of complementary foods formulated from maize, pea, and anchote flours. Food Sci Nutr 8(4):2156-2164

Gernah DI, Sengev Al (2011) Effects of processing on some chemical properties of the leaves of the Drumstick Tree (Moringa oleifera). Nig Food J 29(1):1-12

Gibson EL (2006) Emotional influences on food choice: sensory, physiological and psychological pathways. Physiol Behav 89(1):53-61

Gibson RS, Ferguson EL, Lehrfeld J (1998a) Complementary foods for infant feeding in developing countries: their nutrient adequacy and improvement. Eur J Clin Nutr 52(10):764-770

Gibson RS, Vanderkooy PDS, Thompson L (1998b) Dietary phytatex calcium/ zinc millimolar ratios and zinc nutriture in some Ontario preschool children. Biol Trace Elem Res 30(1):87-94
González-Burgos E, Ureña-Vacas I, Sánchez M, Gómez-Serranillos MP (2021) Nutritional value of Moringa Oleifera Lam. leaf powder extracts and their neuroprotective effects via antioxidative and mitochondrial regulation. Nutrients 13(7):2-23

Hallberg L, Brune M, Rossander L (1989) Iron absorption in man: ascorbic acid and dose-dependent inhibition by phytate. Am J Clin Nutr 49(1):140-144

Hazra B, Santana B, Nripendranath M (2008) Antioxidant and free radicals scavenging activity of Spondias pinnata. J BMC 8(1):20-63

Holdoway A (2021) Tackling malnutrition: improving patient outcomes and reducing demand on healthcare services. Bri J Healthc Manag 27(7):176-181

Ijarotimi OS, Keshinro $\mathrm{OO}$ (2012) Formulation and nutritional quality of infant formula produced from germinated popcorn, bambara groundnut and african locust bean flour. J Microbiol Biotechnol Food Sci 1(1):1358-1388

Ijarotimi SO, Keshinro OO (2013) Determination of nutrient composition and protein quality of potential complementary foods formulated from the combination of fermented popcorn, African locust and Bambara groundnut seed flour. Pol J Food Nutr Sci. https://doi.org/10.2478/ v10222-012-0079-z

Ijarotimi OS, Oluwalana IB (2013) Chemical compositions and nutritional properties of popcorn-based complementary foods supplemented with Moringa oleifera leaves flour. J Food Res 2(6):117-132

Ijarotimi OS, Oluwalana IB, Otutu OI (2011) Nutritive values and sensory evaluation of a potential weaning diet formulated from Sorghum (Sorghum bicolour) and spot prawns (Pandalu splatyceros). Int J Agric Food Sci 2(2):224-238

Ijarotimi OS, Malomo SA, Fagbemi TN, Osundahunsi OF, Aluko RE (2018) Structural and functional properties of Buchholzia coriacea seed flour and protein concentrate at different $\mathrm{pH}$ and protein concentrations. Food Hydrocol 74(2):275-288

Ijarotimi OS, Oluwajuyitan TD, Ogunmola GT (2019) Nutritional, functional and sensory properties of gluten-free composite flour produced from plantain (Musa AAB), tigernut tubers (Cyperus esculentus) and defatted soybean cake (Glycine max). Croat J Food Sci Technol 11(1):1131-1251

lombor TT, Umoh EJ, Olakumi E (2009) Proximate composition and organoleptic properties of complementary food formulated from millet (Pennisetum psychostachynum), soybeans (Glycine max) and crayfish (Euastacus spp). Pak J Nutr 8(10):1676-1679

Irenso AA, Letta S, Chemeda AS, Asfaw A, Egata G, Assefa N, Campbell KJ, Laws $R$ (2021) The facilitators and barriers of adopting amylase-rich flour to enhance complementary foods in the Kersa district community of eastern Ethiopia. Nutr. https://doi.org/10.3390/nu13030838

Itagi HB, Singh V (2012) Preparation, nutritional composition, functional properties and antioxidant activities of multigrain composite mixes. J Food Sci Technol. https://doi.org/10.1007/s13197-011-0267-6

Jaffe CS (2003) Analytical chemistry of food, vol 1. Blackie Academic and Professional, New York, p 200

Jastrzębska A (2009) Modifications of spectrophotometric methods for total phosphorus determination in meat samples. Chem Pap 63(1):47-54

Kakade ML, Rackis JJ, McGhee JE, Puski G (1974) Determination of trypsin inhibitor activity of soy products: a collaborative analysis of an improved procedure. Cereal Chem 51(3):370-376

Kim SW, Mateo RD, Yin YL, Wu G (2007) Functional amino acids and fatty acids for enhancing production performance of sows and piglets. AsianAustral J Anim Sci 20(2):295-306

Klein SM, Cohen G, Cederbaum Al (1981) Production of formaldehyde during metabolism of dimethyl sulfoxide by hydroxyl radical-generating systems. Biochem 20(21):6006-6012

Koletzko B, Cooper P, Makrides M, Garza C, Uauy R, Wang W (2008) Subject index. In Pediatric Nutr Prac, pp 299-305

Landry J, Delhaye S, Jones DG (1992) Determination of tryptophan in feedstuffs: comparison of two methods of hydrolysis prior to HPLC analysis. J Sci Food Agric 58(3):439-441

Lee JH (2013) Polyunsaturated Fatty acids in children. Pediatr Gastroenterol Hepatol Nutr. https://doi.org/10.5223/pghn.2013.16.3.153

Lutter CK, Rivera JA (2003) Nutritional status of infants and young children and characteristics of their diets. J Nutr 133(9):2941S-2949S

Maciel BLL, Costa PN, Filho JQ, Ribeiro SA, Rodrigues FAP, Soares AM, Júnior FS, Ambikapathi R, McQuade ETR, Kosek M, Ahmed T, Bessong P, Kang 
G, Shresthra S, Mduma E, Bayo E, Guerrant RL, Caulfield LE, Lima AAM (2021) Higher energy and zinc intakes from complementary feeding are associated with decreased risk of undernutrition in children from South America, Africa, and Asia. J Nutr. https://doi.org/10.1093/jn/nxaa271

Magalhães PJ, Vieira JS, Gonçalves LM, Pacheco JG, Guido LF, Barros AA (2010) Isolation of phenolic compounds from hop extracts using polyvinylpolypyrrolidone: characterization by high-performance liquid chromatography-diode array detection-electrospray tandem mass spectrometry. J Chromatograp A 1217(19):3258-3268

Malati HA (2021) Study of air-spora over the groundnut fields in Nashik District of Maharashtra, India. Schol J Agric Veterin Sci 2(1):15-19

Martin SL, Matare CR, Kayanda RA, Owoputi I, Kazoba A, Bezner KR, Dickin KL (2021) Engaging fathers to improve complementary feeding is acceptable and feasible in the Lake Zone. Tanzania Mater Child Nutr. https:// doi.org/10.1111/men.13144

Masanja H, Jumbe T, Pacific R (2021) Contribution of fish in improving micronutrients content in complementary foods for children aged 6 to 23 months in Lindi Rural District. Afr J Food Sci 15(5):203-217

Mekuria SA, Kinyuru JN, Mokua BK, Tenagashaw MW (2021) Nutritional quality and safety of complementary foods developed from blends of staple grains and honey bee larvae (Apis mellifera). Int J Food Sci 1 (1):1-10

Mildon A, Francis J, Stewart S, Underhill B, Ng YM, Rousseau C, Ruggiero ED, Dennis C, O'Connor DL, Sellen DW (2021) High levels of breastmilk feeding despite a low rate of exclusive breastfeeding for 6 months in a cohort of vulnerable women in Toronto, Canada. Mater Child Nutr 18:e13260

Miura K, Rus A, Sharkhuu A, Yokoi S, Karthikeyan AS, Raghothama KG, Hasegawa PM (2005) The Arabidopsis SUMO E3 ligase SIZ1 controls phosphate deficiency responses. Proc Nat Acad Sci 102(21):7760-7765

Mohammed MAE, Makki HMM, Mustafa AEMI (2011) Production of cerealbased infant food from Sorghum [Sorghum bicolor (L) Moench] and pigeon pea (Cajanus cajan). Pak J Nutr 10:910-913

Morris ER, Elli R (1985) Usefulness of the dietary phytic acid/zinc molar ratio as an index of zinc bioavailability to rats and humans. Biol Trace Elem Res 19(1):107-117

Mounika M, Hymavathi TV, Barbhai MD (2021) Sensory and nutritional quality of Moringa oleifera leaf powder incorporated multi-millet ready to eat (RTE) snack. Indian J Tradit Know. 20(1):204-209

Muflihatin I, Vestine V, Gandu Eko JS, Swari SJ (2021) Modisco with Moringa Leaf for Improving Childhood's Nutritional Status. In: The first international conference on social science, humanity, and public health, vol 1, no 1, pp 114-117

Nnam NM (2009) Moringa oleifera leaf improves iron status of infants 6-12 months in Nigeria. Int J Food Safety Nutr Public Health 2(2):158-164

Nout MJR, Rombouts FM (1992) Fermentative preservation of plant foods. J Appl Microbiol 73:136-147

Olapade AA, Umeonuorah UC (2014) Chemical and sensory evaluation of African Breadfruit (Treculia africana) seeds processed with alum and trona. Nig Food J 32(1):80-88

Oluwajuyitan TD, Ijarotimi OS, Fagbemi TN, Oboh G (2021) Blood glucose lowering, glycaemic index, carbohydrate-hydrolysing enzyme inhibitory activities of potential functional food from plantain, soy-cake, rice-bran and oat-bran flour blends. J Food Meas Charact 2(1):1-9

Omueti O, Otegbayo B, Jaiyeola O, Afolabi O (2009) Functional properties of complementary diets developed from soybean (Glycine max), groundnut (Arachis hypogea) and crayfish (Macrobrachium SPP). Elect $J$ Environ Agric Food Chem 8(8):563-573

Onwuka Gl, Onwuka ND (2005) The effects of ripening on the functional properties of plantain and plantain based cake. Int J Food Proper 8(2):347-353

Oria M, Harrison M, Stallings VA (2019) National Academies of Sciences, Engineering, and Medicine; Health and Medicine Division; Food and Nutrition Board; Committee to Review the Dietary Reference Intakes for Sodium and Potassium. Diet Ref Intakes Sodium Potassium 1(1):1-10

Osundahunsi OF, Aworh AC (2002) A preliminary study on the use of tempebased formula as a weaning diet in Nigeria. Plant Foods Human Nutr 57(3):365-376

Otegbayo BO (2002) Nutritional quality of soyplantain extruded snacks. Ecol Food Nutr 41(5):463-474
PAHO (2020) Recommended Nutrient Intakes and Population Nutrient Intake Goals for the Caribbean. Washington, D.C.: Pan American Health Organization (PAHO); 2020. License: CC BY-NC-SA 3.0 IGO. pp 56-57

Pelto GH, Levitt E, Thairu L (2003) Improving feeding practices: current patterns, common constraints, and the design of interventions. Food Nutr Bull 24(1):45-82

Perez E (1997) Characterization of starch insolate from plantain (Musa paradisiaca normalis). Starch/starke 1(1):45-49

Polterat O (1997) Antioxidants and free radical Scavengers of natural origin. Curr Organ Chem 1:415-440

Rai M (2021) Nutritional assessment of 6-59 months children of dharan-6, panbari, sunsari nepal (Doctoral dissertation, Department of Nutrition and Dietetics Central Campus of Technology Institute of Science and Technology Tribhuvan University, Nepal 2019)

Re R, Pellegrini N, Proteggente A, Pannala A, Yang M, Rice-Evans C (1999) Antioxidant activity applying an improved ABTS radical cation decolorization assay. Free Radic Biol Med 26(9-10):1231-1237

Rogol AD, Soliman A, Alaaraj N (2021) Growth of malnourished infants and children: how is inflammation involved, pp 1-12

Sandberg AS, Svanberg U (1991) Phytate hydrolysis by phytase in cereals; effects on in vitro estimation of iron availability. J Food Sci 56(5):1330-1333

Sathe SK, Deshpande SS, Salunkhe DK (1982) Functional properties of lupin seed (Lupinus mutabilis) proteins and protein concentrates. J Food Sci 47(2):491-497

Shiriki D, Igyor MA, Gernah DI (2015) Nutritional evaluation of complementary food formulations from maize, soybean and peanut fortified with Moringa oleifera leaf powder. Food Nutr Sci 6:494-500

Solomon M, Owolawashe H (2007) The analyses of amino acid, fatty acid and mineral in legume-cereal based complementary food blend used in Jos, Nigeria. Int J Nutr Well 4(1):3-7

Sreeramulu D, Reddy C, Raghunath M (2009) Antioxidant activity of commonly consumed cereals, millets, pulses and legumes in India, pp 1-12

Thenmozhi S, Rajan S (2015) GC-MS analysis of bioactive compounds in Psidium guajava leaves. J Pharmacog Phytochem 3(5):162-166

Trabelsi S, Nelson SO (2006) Nondestructive sensing of bulk density and moisture content in shelled peanuts from microwave permittivity measurements. Food Contr 17(4):304-311

Tripathi MK, Jadam RS, Kumar A (2021) Quality management system in millet and sorghum. In: Millets and millet technology. Springer, Singapore, pp 363-379

Turnlund JR, King JC, Keyes WR, Gong B, Michel MC (1984) A stable isotope study of zinc absorption in young men: effects of phytate and a-cellulose. Am J Clin Nutr 40(5):1071-1077

UNICEF (2016) Ready-to-Use Therapeutic Food: current outlook www.unicef. org/supply/files. RUTF_Supply_Update_May_2014.pdf

Valentine CJ, Morrow G, Reisinger A, Dingess KA, Morrow AL, Rogers LK (2017) Lactational stage of pasteurized human donor milk contributes to nutrient limitations for infants. Nutrients 9(3):302-320

Van Hal M (2000) Quality of sweet potato flour during processing and storage. Food Rev Int 16(1):1-37

Wang L, Xiao M, Dai S, Song J, Ni X, Fang Y, Jiang F (2014) Interactions between carboxymethyl konjac glucomannan and soy protein isolate in blended films. Carbohyd Polym 101(3):136-145

WHO/FAO (2004) Human vitamin and mineral requirements. Report of a joint FAO/WHO consultation, Bangkok, Thailand. Rome, Italy: Food and Agriculture Organization of the United Nations (FAO) and World

Woldegiorgis AZ, Abate D, Haki GD, Ziegler GR (2015) Major, minor and toxic minerals and anti-nutrients composition in edible mushrooms collected from Ethiopia. J Food Process Technol 6(3):234-244

Yamashiro Y (2021) Nutritional support for patients with Biliary Atresia. In: Introduction to Biliary Atresia, pp 203-208

Yu H, Liu H, Erasmus SW, Zhao S, Wang Q, van Ruth SM (2021) An explorative study on the relationships between the quality traits of peanut varieties and their peanut butters. LWT 1(1):115-126

\section{Publisher's Note}

Springer Nature remains neutral with regard to jurisdictional claims in published maps and institutional affiliations. 